\title{
Assessment of the Energy Impacts of Outside Air in the Commercial Sector
}

Technical Report NREL/TP-550-41955

April 2009

K. Benne, B. Griffith, N. Long, and P. Torcellini National Renewable Energy Laboratory

D. Crawley and T. Logee

U.S. Department of Energy 


\section{Assessment of the Energy Impacts of Outside Air in the Commercial Sector}

K. Benne, B. Griffith, N. Long, and P. Torcellini National Renewable Energy Laboratory

D. Crawley and T. Logee

U.S. Department of Energy

Prepared under Task No. BEC7.1006
Technical Report NREL/TP-550-41955

April 2009

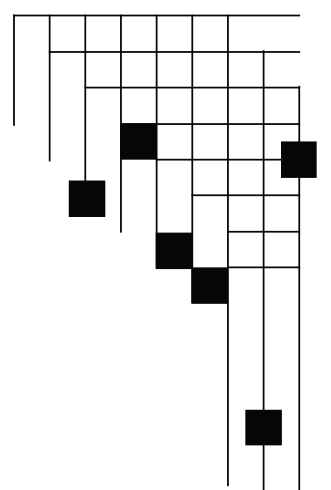




\section{NOTICE}

This report was prepared as an account of work sponsored by an agency of the United States government. Neither the United States government nor any agency thereof, nor any of their employees, makes any warranty, express or implied, or assumes any legal liability or responsibility for the accuracy, completeness, or usefulness of any information, apparatus, product, or process disclosed, or represents that its use would not infringe privately owned rights. Reference herein to any specific commercial product, process, or service by trade name, trademark, manufacturer, or otherwise does not necessarily constitute or imply its endorsement, recommendation, or favoring by the United States government or any agency thereof. The views and opinions of authors expressed herein do not necessarily state or reflect those of the United States government or any agency thereof.

Available electronically at http://www.osti.gov/bridge

Available for a processing fee to U.S. Department of Energy and its contractors, in paper, from:

U.S. Department of Energy

Office of Scientific and Technical Information

P.O. Box 62

Oak Ridge, TN 37831-0062

phone: 865.576 .8401

fax: 865.576 .5728

email: mailto:reports@adonis.osti.gov

Available for sale to the public, in paper, from:

U.S. Department of Commerce

National Technical Information Service

5285 Port Royal Road

Springfield, VA 22161

phone: 800.553.6847

fax: 703.605.6900

email: orders@ntis.fedworld.gov

online ordering: http://www.ntis.gov/ordering.htm 


\section{Contents}

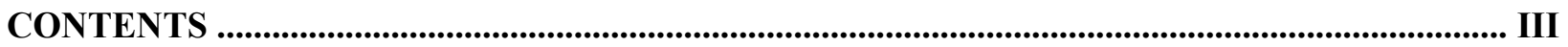

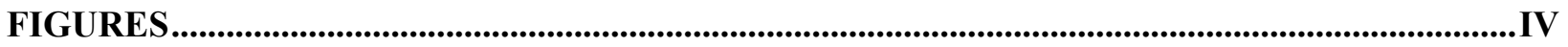

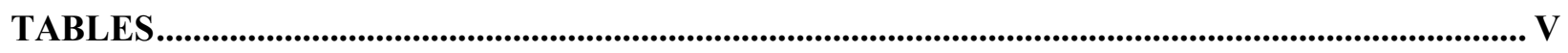

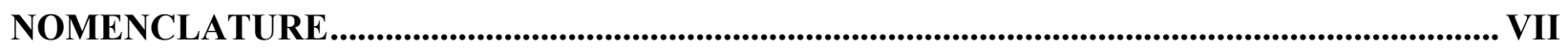

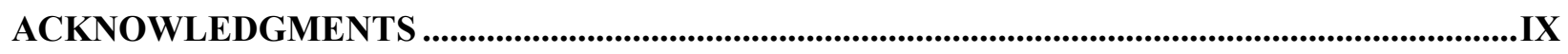

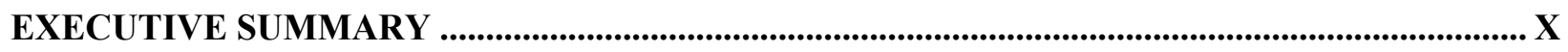

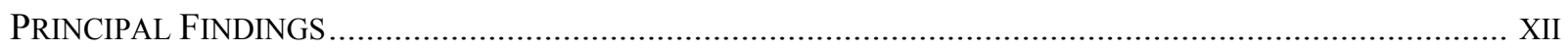

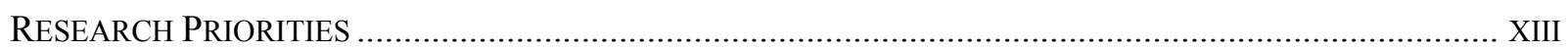

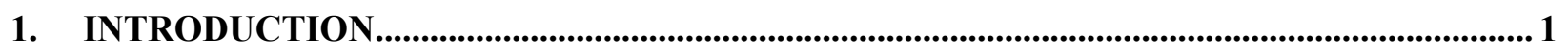

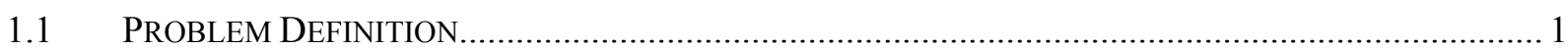

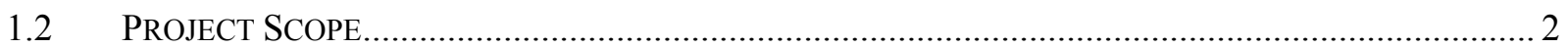

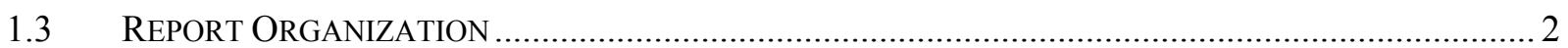

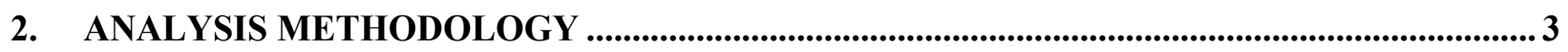

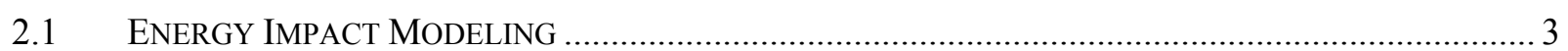

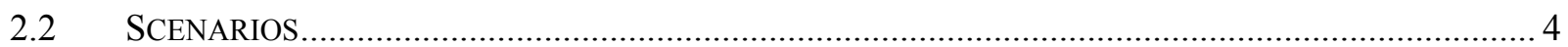

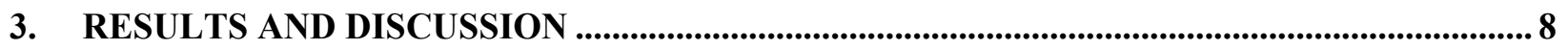

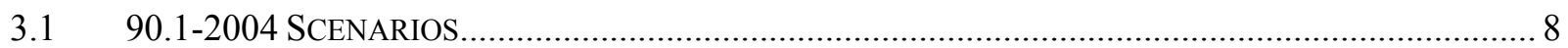

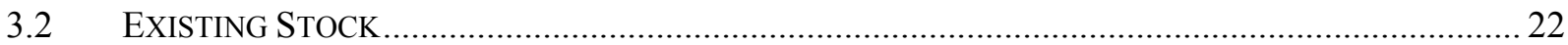

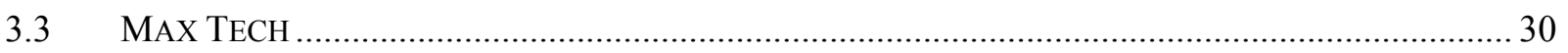

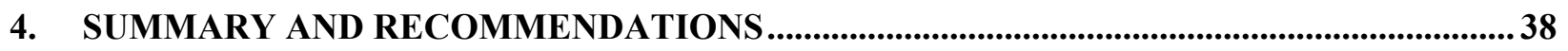

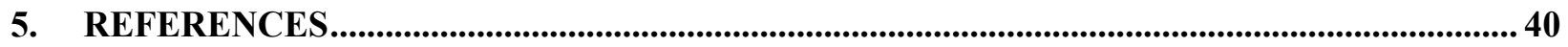




\section{Figures}

Figure ES-1 Sector-Wide Average EUI versus Total ACH for 90.1-2004 Scenarios............................ xiii

Figure 3-1 Sector-Wide Average EUI versus Total ACH for the 90.1-2004 Construction Group........ 10

Figure 3-2 Summary of Percentage Decreases in Sector-Wide Averages .......................................... 14

Figure 3-3 PDF of Change in Sector Average EUI for 90.1-2004, No Minimum Mechanical

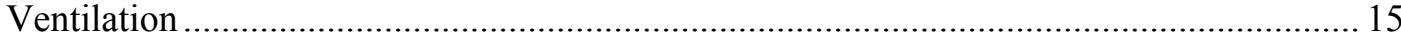

Figure 3-4 PDF of Change in Sector Average EUI for Existing Stock, No Minimum Mechanical

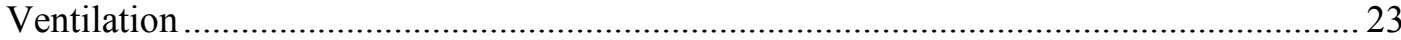

Figure 3-5 PDF of Change in Sector Average EUI for Max Tech, No Minimum Mechanical

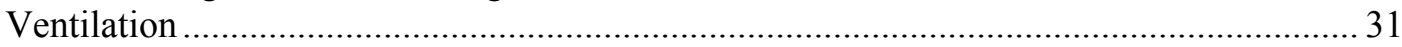




\section{Tables}

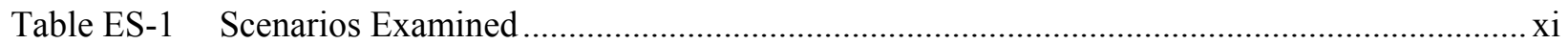

Table 2-1 Default Outside Air Mechanical Ventilation Rates by PBA ..........................................5

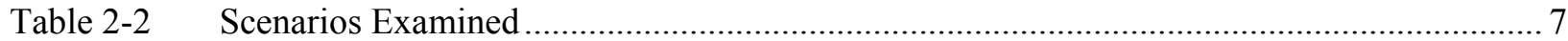

Table 3-1 90.1-2004, Sector-Wide Average Total Site EUI …...................................................... 9

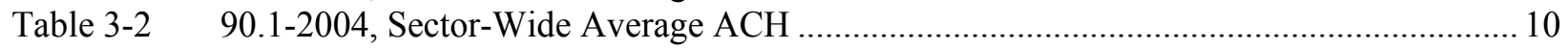

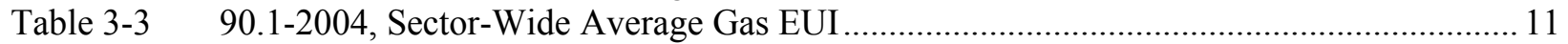

Table 3-4 90.1-2004, Sector-Wide Average Electricity Site EUI ................................................... 12

Table 3-5 90.1-2004, Sector-Wide Average Peak Electric Power .................................................... 13

Table 3-6 Number of Models by Subsectors and Climate Zones ..................................................... 16

Table 3-7 90.1-2004, No Minimum Mechanical Ventilation Scenario, Percent Change in EUI by

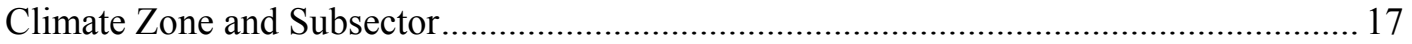

Table 3-8 90.1-2004, No Minimum Mechanical Ventilation, Percent Change in ACH by Climate

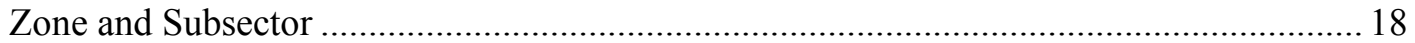

Table 3-9 90.1-2004, No Minimum Mechanical Ventilation, Percent Change in Gas EUI by

Climate Zone and Subsector............................................................................................... 19

Table 3-10 90.1-2004, No Minimum Mechanical Ventilation, Percent Change in Electricity EUI by

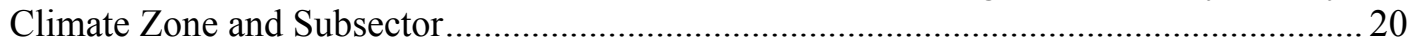

Table 3-11 90.1-2004, No Minimum Mechanical Ventilation, Percent Change in Peak Electrical

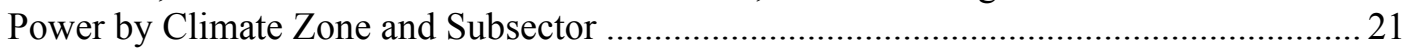

Table 3-12 Existing Stock, Sector-Wide Average Total Site EUI ......................................................2 22

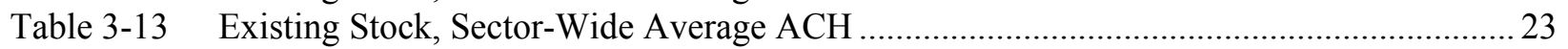

Table 3-14 Existing Stock, Sector-Wide Average Gas EUI ................................................................. 24

Table 3-15 Existing Stock, Sector-Wide Average Electricity EUI ..................................................2 24

Table 3-16 Existing Stock, Sector-Wide Average Peak Electric Power ................................................ 24

Table 3-17 Existing Stock, No Minimum Mechanical Ventilation, Total EUI Percent Change for

Climate Zone and Subsector............................................................................................... 25

Table 3-18 Existing Stock, No Minimum Mechanical Ventilation, ACH Percent Change for Climate Zone and Subsector......................................................................................... 26

Table 3-19 Existing Stock, No Minimum Mechanical Ventilation, Gas EUI Percent Change for Climate Zone and Subsector................................................................................................ 27

Table 3-20 Existing Stock, No Minimum Mechanical Ventilation, Electric EUI Percent Change for Climate Zone and Subsector....................................................................................... 28

Table 3-21 Existing Stock, No Minimum Mechanical Ventilation, Peak Electrical Power Percent

Change for Climate Zone and Subsector .......................................................................... 29

Table 3-22 Max Tech, Sector-Wide Average Total Site EUI ........................................................... 30

Table 3-23 Max Tech, Sector-Wide Average ACH …................................................................. 31

Table 3-24 Max Tech, Sector-Wide Average Gas EUI................................................................ 32

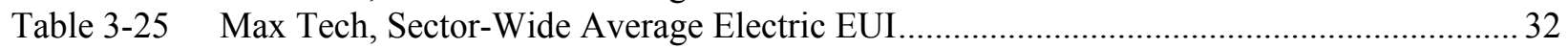

Table 3-26 Max Tech, Sector-Wide Average Peak Electrical Power................................................... 32

Table 3-27 Max Tech, No Minimum Mechanical Ventilation, Total EUI Percent Change for

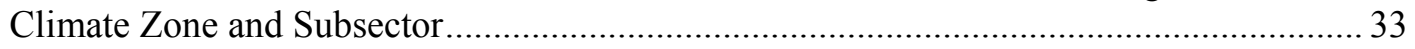

Table 3-28 Max Tech, No Minimum Mechanical Ventilation, ACH Percent Change for Climate

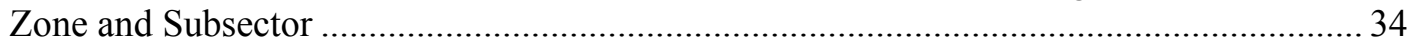

Table 3-29 Max Tech, No Minimum Mechanical Ventilation, Gas EUI Percent Change for Climate

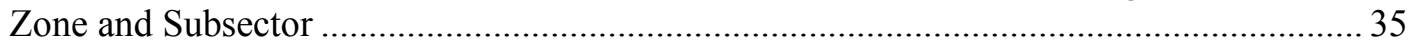

Table 3 -30 Max Tech, No Minimum Mechanical Ventilation, Electric EUI Percent Change for Climate Zone and Subsector. 
Table 3-31 Max Tech, No Minimum Mechanical Ventilation, Peak Electrical Power Percent Change for Climate Zone and Subsector. 


\section{Nomenclature}

$\mathrm{ACH}$-Air Changes per hour.

AEO-Annual Energy Outlook, from EIA.

EIA-Energy Information Administration.

ASHRAE-American Society of Heating, Refrigerating and Air-Conditioning Engineers.

90.1-2004 Construction Group - A group of scenarios that are derived from CBECS, but have modifications to comply with ANSI/ASHRAE/IESNA 90.1-2004. Abbreviated as 90.1-2004 in some contexts.

BT-Building Technologies Program within DOE/EERE.

CBECS-Commercial Buildings Energy Consumption Survey.

DOE-U.S. Department of Energy.

EERE—Energy Efficiency and Renewable Energy.

EUI-Energy Use Intensity.

Existing Stock Construction Group-A group of scenarios that are derived from CBECS to represent the commercial stock of buildings as currently constructed. Abbreviated as Existing Stock in some contexts.

HRV - Heat Recovery Ventilation (include energy and enthalpy recovery).

HVAC-Heating, Ventilating, and Air-Conditioning.

Infiltration - Outside air that is passively introduced through openings in a building's shell.

Max Tech Construction Group-A group of scenarios that are derived from CBECS, but have modifications to better represent expected building technology in the year 2025. Abbreviated as Max Tech in some contexts.

Maximum Mechanical Ventilation-Outside air that can optionally be introduced by the mechanical system for the purpose of economizing, building models that are not equipped with economizers will have a maximum ventilation rate equal to the minimum.

Minimum Mechanical Ventilation-Outside air that is introduced by the mechanical system to meet the fresh air requirements.

NREL_-National Renewable Energy Laboratory.

PDF-Probability Distribution Function.

Perturbation Scenario-A scenario that is based on a reference scenario, but has an adjustment to the outside air.

Reference Scenario-A scenario that is used as a point of comparison in an analysis of the effects of outside air.

Scenario-A group of 4,820 building models derived from CBECS data.

Sector-Energy consumption in the United States is classified by three sectors: transportation, buildings, and industrial.

Subsector-Disaggregation of the sector energy use. As defined by CBECS (EIA 2006b), there are 20 subsectors, or principal building activities, in commercial buildings. These include retail, office, and food sales buildings, and others. Complete listings are provided by Griffith et al. (2008). 
ZEB-Zero energy building (or net zero energy building). A building with net zero energy consumption over one year. Assumed to be based on site energy use. 


\section{Acknowledgments}

This document was prepared under the auspices of Drury Crawley and Terrence Logee of the Building Technologies (BT) Program within the Office of Energy Efficiency and Renewable Energy (EERE) at the U.S. Department of Energy (DOE). The authors would like to thank Michael Brambley, Steven

Emmerich, and Michael Deru for reviewing this work, and Stefanie Woodward and Devin Egan for editing. 


\section{Executive Summary}

We conducted simulation-based research to study the energy impacts of outside air on U.S. commercial buildings stock. We derived detailed building models from 4,820 buildings in the 2003 Commercial Buildings Energy Consumption Survey (CBECS). Combined with the appropriate weighting factors these 4,820 models form the basis of this national scale study. The energy effects of outside air on commercial buildings were analyzed according to three types of construction.

- The commercial sector was analyzed based on a set of models called the Existing Stock Construction Group, which is designed to represent the current CBECS buildings.

- A set of models called the 90.1-2004 Construction Group was created by making the appropriate changes to the existing stock models to make them comply with ANSI/ASHRAE/IESNA standard 90.1-2004 (hereafter simply 90.1-2004).

- A third set of models called the Max Tech Construction Group was created by applying changes to the existing stock models to reflect the technology and construction practices expected by 2025 .

The developments of the basic models used in this study are documented in two related studies, Griffith et al. (2008) and Griffith et al. (2007). EnergyPlus version 2.1 was used to conduct all simulations.

For each building model, two simulations were compared to isolate the energy affects of outside air from the full integrated load. One is established as a reference case, the other has an adjustment to the outside air levels. The only difference between the two models is the outside air rates; thus, it is possible to compare the full integrated energy consumption of the two models and determine the energy impacts related to the change in outside air.

Outside air is analyzed based on two general categories:

- Infiltration, which is uncontrolled, is introduced through openings in the building's shell. The rate depends on relatively complex physics that are related to many variables, including the temperature gradients in the building, relative inside pressure, and the wind exposure of the facade. We simplified the physics by treating infiltration as an empirically derived constant average rate for each annual simulation.

- Mechanical ventilation. A minimum level of ventilation is provided by mechanical systems to provide adequate indoor air quality as specified by ANSI/ASHRAE standard 62.1-2004 (hereafter simply 62.1-2004) and Turk et al. (1989). Some buildings' mechanical systems have economizer controls that can bring in more outside air than the minimum requirement in order to help condition the indoor space. A subset of the buildings in this study also has energy recovery devices that can recover energy from the exhaust air stream of the building through energy transfer to the outdoor air stream. Of the three types of construction we considered, the models in the Existing Stock Construction Group have, on average, the highest levels of minimum ventilation and infiltration. Furthermore, relatively few buildings in the Existing Stock Construction Group have economizer controls and energy recovery devices. The minimum ventilation rates are generally lower in the 90.1-2004 Construction Group models than in the Existing Stock Construction Group. The infiltration rates in the 90.1-2004 Construction Group models remain unchanged. More buildings in 90.1-2004 Construction Group have economizers and energy recovery systems than in the Existing Stock Construction Group. The Max Tech Construction Group, predictably, has the most advanced management of outside air. The minimum ventilation rates are the same as in 90.1-2004 Construction Group, but the infiltration rates are reduced by a factor of 4 to reflect tighter construction. The Max Tech Construction Group models have economizers and energy recovery devices in every building. 
We created a reference set of models for each construction group to establish a point of comparison. Each set of models, called a reference scenario, contains 4,820 models derived from the buildings in the CBECS survey. Each construction group had one perturbation scenario where the minimum ventilation was removed from each of the models. The 90.1-2004 Construction Group was analyzed in more detail then the Existing Stock Construction Group and Max Tech Construction Group. For 90.1-2004 Construction Group, perturbation scenarios were created to analyze the effects of increasing and decreasing the minimum ventilation levels. An additional perturbation scenario was created without any mechanical ventilation, and without the ability to economize. One scenario has infiltration removed so that its effects could be examined. In total, seven scenarios have an adjustment to some aspect of the outside air. All the scenarios used in this study are outlined in Table ES-1.

Table ES-1 Scenarios Examined

\begin{tabular}{|c|c|c|c|c|c|c|}
\hline \multirow{2}{*}{$\begin{array}{c}\text { Construction } \\
\text { Group }\end{array}$} & \multirow{2}{*}{ Scenario } & \multicolumn{2}{|c|}{$\begin{array}{c}\text { Infiltration Rate } \\
\text { (at } 4 \mathrm{~Pa} \text { ) }\end{array}$} & \multirow{2}{*}{$\begin{array}{l}\text { Ventilation } \\
\text { Rate }\end{array}$} & \multirow{2}{*}{ Economizer } & \multirow{2}{*}{$\begin{array}{c}\text { Heat } \\
\text { Recovery } \\
\text { Ventilation }\end{array}$} \\
\hline & & $\mathrm{m}^{3} / \mathrm{s} \cdot \mathrm{m}^{2}$ & $\mathrm{cfm} / \mathrm{ft}^{2}$ & & & \\
\hline $\begin{array}{l}\text { Existing } \\
\text { Stock }\end{array}$ & Reference & 2.68E-04 & 0.060 & $\begin{array}{c}\text { Turk et al. } \\
(1989)\end{array}$ & $\begin{array}{l}\text { Varies by } \\
\text { building }\end{array}$ & $\begin{array}{c}\text { Varies by } \\
\text { building }\end{array}$ \\
\hline $\begin{array}{l}\text { Existing } \\
\text { Stock }\end{array}$ & $\begin{array}{l}\text { No Minimum } \\
\text { Mechanical } \\
\text { Ventilation }\end{array}$ & 2.68E-04 & 0.060 & $\begin{array}{l}\text { Zero unless } \\
\text { in economizer } \\
\text { mode }\end{array}$ & $\begin{array}{l}\text { Varies by } \\
\text { building }\end{array}$ & $\begin{array}{l}\text { Varies by } \\
\text { building }\end{array}$ \\
\hline $90.1-2004$ & Reference & 2.68E-04 & 0.060 & $\begin{array}{l}\text { As required } \\
\text { by } 62.1-2004\end{array}$ & $\begin{array}{l}\text { Where } \\
\text { required by } \\
90.1-2004\end{array}$ & $\begin{array}{l}\text { Where } \\
\text { required by } \\
90.1-2004\end{array}$ \\
\hline $90.1-2004$ & No Infiltration & 0.00 & 0.000 & $\begin{array}{l}\text { As required } \\
\text { by } 62.1-2004\end{array}$ & $\begin{array}{c}\text { Where } \\
\text { required by } \\
90.1-2004\end{array}$ & $\begin{array}{c}\text { Where } \\
\text { required by } \\
90.1-2004\end{array}$ \\
\hline $90.1-2004$ & $\begin{array}{c}\text { No } \\
\text { Mechanical } \\
\text { Ventilation }\end{array}$ & 2.68E-04 & 0.060 & 0.0 & No & $\begin{array}{c}\text { Not } \\
\text { Applicable }\end{array}$ \\
\hline $90.1-2004$ & $\begin{array}{l}\text { No Minimum } \\
\text { Mechanical } \\
\text { Ventilation }\end{array}$ & 2.68E-04 & 0.060 & $\begin{array}{l}\text { Zero unless } \\
\text { in economizer } \\
\text { mode }\end{array}$ & $\begin{array}{l}\text { Where } \\
\text { required by } \\
90.1-2004\end{array}$ & $\begin{array}{l}\text { Where } \\
\text { required by } \\
90.1-2004\end{array}$ \\
\hline $90.1-2004$ & $\begin{array}{c}\text { Half } \\
\text { Minimum } \\
\text { Mechanical } \\
\text { Ventilation }\end{array}$ & 2.68E-04 & 0.060 & $\begin{array}{l}\text { Half of } 62.1- \\
2004 \\
\text { requirements }\end{array}$ & $\begin{array}{l}\text { Where } \\
\text { required by } \\
90.1-2004\end{array}$ & $\begin{array}{l}\text { Where } \\
\text { required by } \\
90.1-2004\end{array}$ \\
\hline $90.1-2004$ & $\begin{array}{l}\text { Double } \\
\text { Minimum } \\
\text { Mechanical } \\
\text { Ventilation }\end{array}$ & 2.68E-04 & 0.060 & $\begin{array}{l}\text { Double } 62.1- \\
2004 \\
\text { requirements }\end{array}$ & $\begin{array}{l}\text { Where } \\
\text { required by } \\
90.1-2004\end{array}$ & $\begin{array}{l}\text { Where } \\
\text { required by } \\
90.1-2004\end{array}$ \\
\hline Max Tech & Reference & 6.69E-05 & 0.015 & $\begin{array}{l}\text { As required } \\
\text { by } 62.1-2004\end{array}$ & Yes & Yes \\
\hline Max Tech & $\begin{array}{l}\text { No Minimum } \\
\text { Mechanical } \\
\text { Ventilation }\end{array}$ & 6.69E-05 & 0.015 & $\begin{array}{l}\text { Zero unless } \\
\text { in economizer } \\
\text { mode }\end{array}$ & Yes & Yes \\
\hline
\end{tabular}




\section{Principal Findings}

- The minimum mechanical ventilation in the reference models increases the commercial sector average energy use intensity (EUI) by $6.6 \%, 5.2 \%$, and $0.7 \%$ for the Existing Stock, 90.1-2004, and Max Tech construction groups, respectively. The relative magnitude of the effect is smallest for the Max Tech Construction Group and greatest for the Existing Stock Construction Group. The impact of mechanical ventilation is more significant on older vintages of construction because outside air management in new buildings is improved. Heat recovery devices are included in many new construction (90.1-2004 Construction Group) buildings and in all Max Tech Construction Group buildings.

- The natural gas EUIs follow a similar trend as the total EUIs. Minimum mechanical ventilation increases the energy consumption by $21.4 \%, 20.3 \%$, and $8.9 \%$ for the Existing Stock, 90.1-2004, and Max Tech construction groups, respectively.

- The required ventilation decreases or has no effect on the electricity EUIs. The change is undetectable, 0.0\%, for the Existing Stock and a 2.8\% and 3.1\% decrease for the 90.1-2004, and Max Tech Construction Groups respectively. Surprisingly, the minimum ventilation reduces the average electric EUI even for the Max Tech Construction Group, where all buildings are equipped with economizers. Controls in the economized buildings should bring in outside air when it is beneficial, even if the minimum ventilation rate is zero. The economizer controls in the simulations presumably missed opportunities to economize.

- The sector average EUI is plotted versus the air change rate, expressed in air changes per hour (ACH), for the 90.1-2004 Construction Group in Figure ES-1. The series of connected points from left to right represents scenarios in the 90.1-2004 Construction Group with no minimum, half minimum, reference, and double minimum levels of ventilation. A significant amount of information can be obtained from this figure by differencing two points. It is probably most significant that the relationship between the total EUI and $\mathrm{ACH}$ is nonlinear among the scenarios with varying ventilation rates. The nonlinear outcome reveals that outside ventilation air is costlier at higher ventilation rates.

- Figure ES-1 also shows two outlying points corresponding to scenarios in the 90.1-2004 Construction Group with no mechanical ventilation and no infiltration. Comparing the two points to the reference scenario suggests that, based on the sector average, a quantity of outside air provided by mechanical ventilation consumes less energy than an equivalent volume of outside air passively introduced because of infiltration. The outcome is consistent with expectations, because mechanical ventilation systems can take advantage of heat recovery. The trend is based purely on the overall sector average (and constant, annual average infiltration) and does not apply to every climate and building. The detailed results contained in the body of this report show that for some climates infiltration actually reduces the overall EUI of a building, presumably because of passive economizing. 


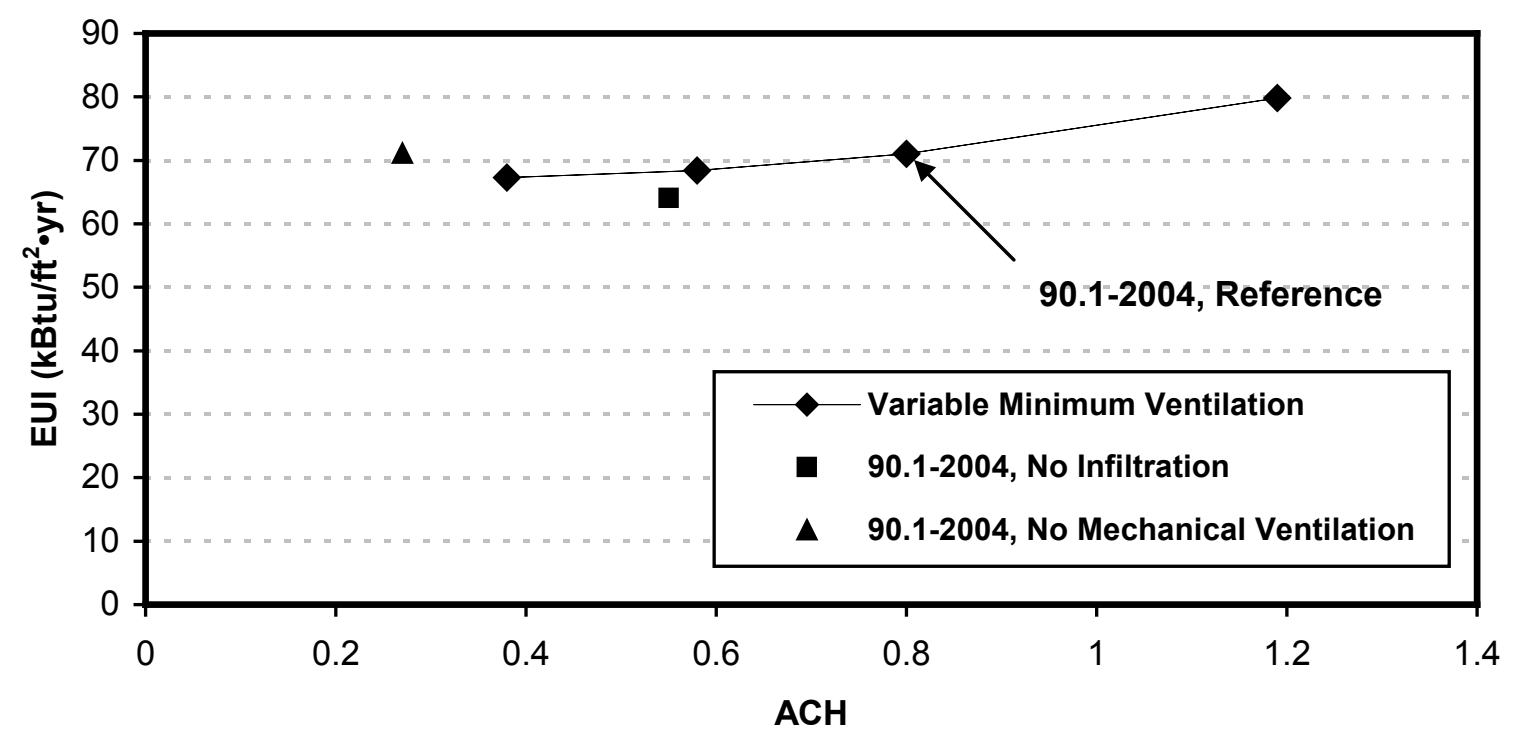

Figure ES-1 Sector-Wide Average EUI versus Total ACH for 90.1-2004 Scenarios

- Detailed results based on climate zone and subsector are included in the body of this report; however, we concluded that in many cases there are too few building models in the CBECS data set to provide a statistically accurate sample. In climate zones and subsectors that have only a few building models, a single non-prototypical building may skew the results.

\section{Research Priorities}

This assessment shows that the energy consumed as a result of outside air is a significant fraction of a building's overall energy consumption. When gas energy is associated primarily with heating, and electric energy is associated mostly with cooling, the results can provide a basic indicator of the effect outside air has on heating and cooling energy. It was found that gas energy consumption is particularly affected by outside air, especially in colder climates. We also found that on average electrical energy decreased as a result of mechanical ventilation, but for buildings with economizers this outcome seems to be attributed to poor economizer controls. This research shows that the energy associated with ventilation increases slightly nonlinearly with the ventilation rate, so the energy impact of increasing the rate would be underestimated if a linear extrapolation with a narrow perturbation range were used. Despite the significant energy penalty, there is continuing pressure to increase ventilation rates to improve occupant health. We recommend several areas where further research would be beneficial.

- Investigate advanced energy recovery systems to reduce the energy consumed by mechanical ventilation. Developments in fundamental heat transfer would apply to energy recovery in buildings and to a wide range of mechanical systems. Current technology could benefit from a study of the most effective building types and locations to apply energy recovery devices. The performance of all heat recovery systems could be improved by implementing advanced controls that could bypass the system when the associated increase in fan energy was greater than the savings achieved by energy recovery.

- Develop improved economizing controls. We identified instances where required ventilation reduces cooling energy consumption, even when economizers are installed. Economizing systems could be improved by developing control mechanisms that more effectively identify conditions when economizing can save energy. The optimal system should identify economizing 
opportunities and provide ventilation independent of the fresh air requirement. Although the conclusion that economizing control should be improved is based on simulation, the control systems in real buildings are thought to have the same shortcomings.

- Improve infiltration modeling. The effect of infiltration was given less emphasis, but the 90.12004 Construction Group simulations predict that a significant energy penalty is associated with infiltration. Infiltration is sometimes beneficial, but it typically consumes more energy per volume of outside air than mechanical ventilation. Nevertheless, building infiltration is a complex phenomenon that is modeled crudely in the present methodology, which uses constant annual average rates. The infiltration rates specified in the models of this study are merely estimates, and research is needed to more accurately model this form of outside air. Models are available in EnergyPlus to develop a detailed air flow network; however, applying these methods to the large number of unique buildings in this study is impractical.

- Improve the accuracy of detailed results. The limited number of buildings in the CBECS survey reduces the accuracy of detailed results. This deficiency could be improved by either developing a set of building models based on a larger number of samples, or more practically by using a set of prototypical benchmark buildings as the basis of the investigation. A smaller set of prototypical buildings would make it feasible to focus on individual models.

- Investigate alternative methods of producing a healthy indoor environment. Advanced filters and ultraviolet light might reduce the necessary ventilation rates, but at the expense of new parasitic losses. The energy implications of these alternatives should be investigated and compared to the cost of conventional ventilation.

- Fully implement building standards and ensure compliance. Significant energy savings can be achieved simply by ensuring that standards are followed. Much of this report focuses on improving on a very optimistic scenario where all buildings are tightly sealed and have economizers and heat recovery. Improved governance based on current understanding is at least as important as technical advancements. 


\section{Introduction}

\subsection{Problem Definition}

The Energy Information Agency (EIA 2006a) reports that in 2005, U.S. commercial buildings consumed 18 quads of energy, accounting for nearly $18 \%$ of the nation's total energy consumption. The energy supply is becoming increasingly limited, and the energy demand continues to increase. The energy used by commercial buildings places a significant burden on the nation's finite energy supply. To address this concern, the U.S. Department of Energy has set an aggressive goal to reduce the energy consumption of the commercial sector of buildings to net zero. Research on how best to achieve net zero energy buildings (ZEBs) is ongoing although a recent study by the National Renewable Energy Laboratory (NREL) found that net zero energy across the sector is possible if the current best technologies are used in combination with an integrated, whole-building design approach (Griffith et al. 2008).

The purpose of this study is to analyze the effects of outside air on the energy performance of a building. There is as yet no consensus, but the viability of ZEBs could be significantly influenced by the effects of outside air. A detailed assessment of these effects is needed to determine the significance of outside air and to direct future study toward the most viable ways to achieve energy savings, assuming the effects of outside air are significant.

A study of the energy implications of outside air presents two significant challenges.

- We need to accurately quantify the amount of outside air that enters a building. There is not a direct method to physically measure the amount of outside air entering a building. One approach is to use various tracer gas techniques (Harrje et al. 1985), which can determine the amount of outside air - although these are typically short-term tests and extrapolation can be problematic because of the variables affecting the rate. Experimental techniques are also very expensive to apply on a reasonably-sized sample of the U.S. commercial buildings stock.

- There is no method to directly measure the energy impacts of outside air, because the system loads related to outside air are coupled with the full integrated load on the HVAC equipment. The difficulty in isolating outside air loads and the challenge in simply measuring outside air rates can be at least partially overcome with energy simulations, but even with simulation isolating the effects of the outside air is difficult.

Assuming these obstacles can be overcome, a detailed national scale analysis remains complicated by the sheer number of dependent variables involved. Two important variables that this study attempts to isolate are the outdoor climate and the means by which outside air is introduced to the building.

A few publications address the energy implications of outside air, but many more focus on the benefits of increased ventilation without fully taking into account the energy requirements (Fisk 2000). One study that does address the energy associated with outside air is by Eto et al. (1988). Eto used the DOE 2.1C modeling software to study the energy implications of outside air for a single office building swept over 13 climates in the United States and Canada. They concluded that increasing the ventilation rate has only a small impact on a building's overall energy consumption. Nevertheless, a fourfold increase in the ventilation rate resulted in an $8 \%$ heating energy increase and a $14 \%$ cooling energy increase in the most extreme climates.

Colliver (1995) used a theoretical analysis to determine the annual energy required to condition a specified rate of outside air to the indoor set point conditions. This analysis used hourly weather data to determine realistic outdoor conditions; both sensible and latent energy were taken into account. In Los Angeles, the annual normalized energy requirement of outside air was determined to be $22.1 \mathrm{MJ} \cdot \mathrm{h} / \mathrm{kg}$; in Omaha it was $102.5 \mathrm{MJ} \cdot \mathrm{h} / \mathrm{kg}$. Colliver concluded that the energy associated with ventilation was significant. 
Emmerich et al. (2005) published a report on the energy effects of outside air using an analysis based on three building types swept across five representative U.S. cities. This study was carried out using detailed simulations based on the Multizone Airflow and Contaminant Transport Analysis Software (CONTAMW), coupled with a detailed multi-zone building model in the Transient Energy System Simulation Tool (TRNSYS). An analysis was made of the energy cost savings potential of increasing the air tightness of each building. The results predicted a 3\% to $36 \%$ savings in annual heating and cooling energy.

This study uses a much simpler airflow model compared to the work of Emmerich et. al.; however, the focus here is to assess a large representative sampling of the U.S. commercial buildings stock. This work is based around several sets of building models derived from the 4,820 buildings in the 2003 Commercial Buildings Energy Consumption Survey (CBECS) (2006b).

\subsection{Project Scope}

This report provides a detailed analysis of the effects of outside air on U.S. commercial buildings. The objectives are to quantify the energy use associated with various forms of outside air and to identify research areas that have potential to advance high-performance building technology.

The means by which outside air is brought into a building is important. For this research, three methods of introducing outside air are studied:

- Infiltration through the building's shell.

- Mechanical ventilation necessary to provide suitable indoor air quality as specified by ANSI/ASHRAE standard 62.1-2004 and Turk et al. (1989).

- Mechanical ventilation used for economizing.

The effects of each form of outside air are analyzed individually. We aggregated the results into 14 climate zones and 18 subsectors of the U.S. commercial buildings stock.

The commercial sector is further analyzed, based on three levels of construction quality. One level of construction is designed to represent the existing stock of commercial buildings. Another level of construction is based on a generally improved set of buildings based on ASHRAE 90.1-2004. The third level is based on the expected technology and construction practices in 2025.

The intent of this work is specifically to identify the energy impacts of outside air. The analysis is based on answering a series of "what if" questions. We look at what happens if building construction quality and mechanical equipment are improved. What happens if mechanical ventilation is cut in half? What if it is doubled? It is not in the scope of this work to assess the appropriate levels of outdoor air. We aim to inform decision makers of the national-scale energy impacts of decisions related to changing outside air requirements.

\subsection{Report Organization}

This report is divided into five sections:

Section 1 introduces the problem and identifies the research motivation and objectives.

Section 2 outlines the methodology used to evaluate the effects of outside air.

Section 3 presents the results of the study along with a discussion of important outcomes.

Section 4 includes a discussion of the recommendations based on this research, including suggestions for future research.

Section 5 is a list of references. 


\section{Analysis Methodology}

For an assessment of the energy impacts of outside air, national-scale results based on a large number of buildings are valuable. To meet this need, we carried out detailed building simulations based on 4,820 buildings in the 2003 CBECS public-use data using EnergyPlus version 2.1. By applying the appropriate weighting factors, the buildings in the CBECS data set were used to represent the entire U.S. commercial buildings stock. The methodology used to create detailed models from the survey data has been thoroughly documented in two previous NREL studies: Griffith et al. (2007; 2008). The models created for those works form the basis of this analysis.

\subsection{Energy Impact Modeling}

Modeling the energy impacts of outside air is difficult because of the complex interactions between HVAC components and the thermal zone. The difficulty arises in determining exactly how one small portion of an integrated load is supposed to be propagated back through all the components of an arbitrarily complex HVAC system. The ventilation load data from a single model might be used to make simplifying assumptions and model the energy impacts; however, our approach is to use multiple simulations. A methodology based on adjusting inputs and comparing multiple runs is common when detailed, whole-building simulation programs such as EnergyPlus are used. Calculating the differences in energy use results between simulations appears to be the most useful way to apply EnergyPlus to the question of outside air impact on energy. The basic method used here is to run two simulations: one reference simulation with a typical rate for outside air, and another simulation with a prescribed change in the outside air rate. The whole-building integrated energy use results are compared, and because the only difference in the models is in the outside air rate, we attribute all the changes in energy use to that change.

The method of comparing energy use across multiple simulations is an obvious choice for modeling the energy impacts of outside air with EnergyPlus, but in practice the issue of autosizing HVAC systems complicates the approach. Outside air is an important contributor to the integrated load calculations used to size system component capacities. If two models with different levels of outside air are automatically sized, the simulations will differ in many more ways, because the system capacities would be different. For example, a constant volume air system that provides no outside air will be smaller than a similar system that does provide outside air. The air system with a smaller design will have less fan energy than the larger air system. Although the implications of outside air could be evaluated in such a way that the system size differences are taken into account, it is simpler not to allow such secondary and complex changes to occur. When using perturbation and differencing methods to calculate integrated effects on whole-building energy use, it is preferable to control exactly how the models differ.

To avoid the complexities of autosizing, in most cases we used hard sizes in the EnergyPlus input files. The building models are derived from models that were initially autosized, but then hard size files were created by using the results from previous autosizing. In the hard-sized EnergyPlus models, all the inputs are fixed and there are no input objects related to sizing. In theory, the hard-sized and autosized simulations should be identical; in practice, negligible differences are observed because of round-off differences. The one exception for autosizing is when outside air was increased from the levels in the reference simulation. In this case the model was autosized to allow adequate system capacity to meet the required indoor conditions.

For each building model, three parameters are used to control the outside air rates that are important to this work:

- Infiltration rate. This prescribes the amount of outside air that is unintentionally introduced through openings in the building's shell. Our modeling approach treats infiltration as a constant annual rate. The physical complexities of infiltration are simplified by our approach. Detailed air 
flow models are available; however, they were considered impractical to implement for the large number of models in this study.

- Minimum mechanical ventilation rate. This controls the amount of outside air that is introduced by the mechanical system to provide fresh air.

- Maximum mechanical ventilation rate. This comes into play with an economizer system. It determines the rate of outside air that the building's mechanical system is capable of delivering.

The building is modeled without an economizer by setting the maximum ventilation rate equal to the minimum. When the maximum ventilation rate is set above the minimum, controls in the HVAC system can provide ventilation up to the maximum rate for economizing. The maximum ventilation rate is not a requirement. Buildings in poor economizing climates can remain at the minimum ventilation rate for the entire simulation if controls determine that economizing does not save energy.

\subsection{Scenarios}

For this study, the commercial stock of buildings is analyzed based on three levels of construction quality and building technology. Each group of models belonging to a particular level is referred to as a construction group. One construction group, which we call the Existing Stock Construction Group, aims to represent the commercial sector as it is constructed today. Another construction group, the 90.1-2004 Construction Group, has the necessary changes to make the existing stock of buildings comply with 90.12004. A third construction group, called the Max Tech Construction Group, is based on reconstructing the current stock of buildings using future advanced technology and construction practices.

Within each construction group several sets of 4,820 models are created based on the CBECS data. We call each group of 4,820 models a scenario. Each construction group contains a "reference scenario" and at least one "perturbation scenario" that has a change to the outside air levels. The reference scenarios most correctly represent each construction group. The scenarios with changes to the outside air levels are necessitated by our approach in determining the effects of outside air.

The process of creating complete building models for the Existing Stock Construction Group is documented by Griffith et al. (2008). Griffith et al. (2007) documents the series of changes that were made to the existing stock models in order to create the 90.1-2004 and Max Tech construction groups. In this report, our intent is to investigate the effects of outside air, so we focus on the details of the models pertaining to infiltration and mechanical ventilation.

\subsubsection{Existing Stock}

Complete details about the Existing Stock Construction Group models are documented in previous work, but here we focus on the details pertaining to outside air. Following the previous work, infiltration is modeled as a simple constant air change rate that is the result of combining a flow rate per exterior area with a whole-zone air change rate that is the same for all zones. Based on Persily (1998) we assumed a leakage rate per exterior area of $0.4 \mathrm{cfm} / \mathrm{ft}^{2}$ at $75 \mathrm{~Pa}$. The leakage rate is a factor of 4 lower than the mean value of $1.67 \mathrm{cfm} / \mathrm{ft}^{2}$ at $75 \mathrm{~Pa}$ reported by Persily. Leakage rates are typically characterized at relatively high pressure differences $(75 \mathrm{~Pa})$; however, in practice the differential pressure seen by a building is lower and variable depending on stack, wind, and mechanical ventilation effects. We used the relationship $\dot{V} / A=C \Delta P^{n}$, where $n=0.65$, combined with the infiltration rate at $75 \mathrm{~Pa}$, to arrive at the infiltration rate for the existing stock models, $0.0002677 \mathrm{~m} / \mathrm{s} \cdot \mathrm{m}^{2}$ at $4 \mathrm{~Pa}$.

In addition to the infiltration rate that is a function of the building envelope area, a whole-zone air change rate is applied to all zones. The magnitude of the whole zone infiltration rate was assigned, by assumption, by taking $10 \%$ of a randomly assigned level determined using a lognormal probability distribution for infiltration found by Chan (2006). Chan's modeling study found infiltration rates in the commercial sector to have a lognormal distribution with geometric mean of 0.35 and a geometric standard deviation of 2.1 . 
Most HVAC systems use outside air ventilation to gradually purge the impurities in stale indoor air. Like infiltration, data pertaining to real world ventilation rates are limited, and much of the information combines mechanical ventilation and infiltration. Turk et al. (1989) used tracer gas techniques to measure combined infiltration and ventilation rates in 38 commercial buildings in the Pacific Northwest. They found mean outside air rates of 1.5 air changes per hour $(\mathrm{ACH})$ or $28 \mathrm{l} / \mathrm{s} \cdot$ person $(59.3 \mathrm{cfm} /$ person $)$, and provided a breakdown for educational, libraries, small and large offices, and multi-use buildings. We modeled ventilation by assuming that the infiltration portion is equivalent to $9.3 \mathrm{l} / \mathrm{s} \cdot$ person $(19.7$ $\mathrm{cfm} /$ person), then subtracted the rate for infiltration from the whole-building ventilation rates reported by Turk et al. to assemble default rates for mechanical ventilation. For activity types not covered, the mean rate without infiltration of $18.8 \mathrm{l} / \mathrm{s} \cdot$ person $(39.8 \mathrm{cfm} /$ person) was used. The mechanical ventilation rates that are used for each principal building activity (PBA) of the existing stock models are given by Table 21. The rates are generally in excess of the minimum levels specified in 62.1-2004, except for education, which is close but slightly low.

Table 2-1 Default Outside Air Mechanical Ventilation Rates by PBA

\begin{tabular}{|c|l|c|c|l|}
\hline $\begin{array}{c}\text { PBA } \\
\text { Code }\end{array}$ & \multicolumn{1}{|c|}{ PBA Name } & $\begin{array}{c}\text { Default Outside } \\
\text { Air Rate } \\
\text { (cfm/person) }\end{array}$ & $\begin{array}{c}\text { Default Outside } \\
\text { Air Rate } \\
\text { (l/s-person) }\end{array}$ & Data Source \\
\hline \hline 1 & Vacant & 0.0 & 0.0 & (assumption) \\
\hline 2 & Office/professional $<9300 \mathrm{~m}^{2}$ & 55.3 & 26.1 & Turk et al. 1989 \\
\hline 2 & Office/professional $>9300 \mathrm{~m}^{2}$ & 45.3 & 21.4 & Turk et al. 1989 \\
\hline 4 & Laboratory & 39.6 & 18.7 & Turk et al. 1989 \\
\hline 5 & Nonrefrigerated warehouse & 10.6 & 5.0 & (assumption) \\
\hline 6 & Food sales & 39.6 & 18.7 & Turk et al. 1989 \\
\hline 7 & Public order and safety & 39.6 & 18.7 & Turk et al. 1989 \\
\hline 8 & Outpatient health care & 39.6 & 18.7 & Turk et al. 1989 \\
\hline 11 & Refrigerated warehouse & 4.2 & 2.0 & (assumption) \\
\hline 12 & Religious worship & 39.6 & 18.7 & Turk et al. 1989 \\
\hline 13 & Public assembly & 39.6 & 18.7 & Turk et al. 1989 \\
\hline 14 & Education & 13.4 & 6.3 & Turk et al. 1989 \\
\hline 15 & Food service & 39.6 & 18.7 & Turk et al. 1989 \\
\hline 16 & Inpatient health care & 39.6 & 18.7 & Turk et al. 1989 \\
\hline 17 & Skilled nursing & 39.6 & 18.7 & Turk et al. 1989 \\
\hline 18 & Lodging & 39.6 & 18.7 & Turk et al. 1989 \\
\hline 25 & Retail & 39.6 & 18.7 & Turk et al. 1989 \\
\hline 26 & Service & 39.6 & 18.7 & Turk et al. 1989 \\
\hline 91 & Other & 39.6 & 18.7 & Turk et al. 1989 \\
\hline
\end{tabular}

The minimum ventilation rate is the minimum level of outside air that is required for occupant health. When an airside economizing system is present, the minimum rate can be exceeded to provide inexpensive cooling. Only a subset of the existing stock is equipped with economizer controls, and in this study the presence of economizing controls is determined from the CBECS data. In order to model an airside economizer, the maximum ventilation rate is set to the capacity of the supply fan, thereby allowing the system to provide up to $100 \%$ outside air when it is advantageous to economize.

Only a subset of the existing stock also has energy recovery systems. For the Existing Stock Construction Group modeling scenarios, the presence of these devices is again determined from the CBECS survey data. 


\subsubsection{1-2004}

The models in the 90.1-2004 Construction Group are created by applying the necessary changes to make the Existing Stock Construction Group models comply with the 90.1-2004 standard. As documented by Griffith et al. (2007), changes are made to items such as lighting power density (LPD), thermal envelope constructions, and mechanical efficiencies. System types are also modified to reflect the eight system types specified in Table G3.1.1A of 90.1-2004 Appendix G. Most pertinent to this study is that minimum mechanical ventilation rates are set to the minimum specified by 62.1-2004. For the 90.1-2004 reference scenario, infiltration rates remain the same as in the Existing Stock Construction Group models, because 90.1-2004 has no air tightness requirements. Economizers and heat recovery devices are used where they are required by 90.1-2004. There are more buildings in the 90.1-2004 Construction Group with economizers and heat recovery devices than in the Existing Stock Construction Group.

\subsubsection{Max Tech}

The models in the Max Tech Construction Group were developed by applying changes to the existing stock models that reflect the best available technology and energy-saving practices expected in 2025 . Similar to the 90.1-2004 Construction Group models, changes are made to items such as LPD, thermal envelope constructions, and mechanical efficiencies. Again, the system types are modified to reflect the eight system types specified in Table G3.1.1.A of 90.1-2004. The reference scenario models in the Max Tech Construction Group are also fully documented by Griffith et al. (2007).

For the reference models in the Max Tech Construction Group, infiltration rates are reduced by a factor of 4 compared to the existing stock models to reflect an improved envelope construction. The minimum mechanical ventilation rates are set to the minimum specified by 62.1-2004, the same as the 90.1-2004 reference scenario. The reference models in the Max Tech Construction Group have economizers and heat recovery devices for all buildings.

\subsubsection{Summary of Outside Air Scenarios}

The details pertaining to the outside air of each scenario are summarized in Table 2-2. There are three reference scenarios, one corresponding to each construction group. The infiltration rate is the same for the Existing Stock and 90.1-2004 reference scenarios; the Max Tech reference scenario has reduced infiltration to reflect a tighter envelope. Ventilation is the same for the 90.1-2004 and Max Tech reference scenarios, and slightly higher for the existing stock reference scenario. A larger number of buildings in the 90.1-2004 reference include economizers and heat recovery devices compared to the Existing Stock. All buildings in the Max Tech reference have economizers and heat recovery devices.

In addition to the three reference scenarios, seven perturbation scenarios are created, which modify the reference outside air rates. Each construction group has a scenario that removes all minimum mechanical ventilation. The 90.1-2004 Construction Group is analyzed in more detail than the other two groups. For the 90.1-2004 Construction Group, five perturbation scenarios adjust the outside air rates from the reference.

All infiltration rates reported in Table 2-2 include only the infiltration per shell area. As noted in previous discussion, there is a statistically random whole zone infiltration rate applied to all models in addition to the rates reported in the table. 
Table 2-2 Scenarios Examined

\begin{tabular}{|c|c|c|c|c|c|c|}
\hline \multirow{2}{*}{$\begin{array}{c}\text { Construction } \\
\text { Group }\end{array}$} & \multirow{2}{*}{ Scenario } & \multicolumn{2}{|c|}{$\begin{array}{c}\text { Infiltration Rate } \\
\text { (at } 4 \mathrm{~Pa})\end{array}$} & \multirow{2}{*}{$\begin{array}{l}\text { Ventilation } \\
\text { Rate }\end{array}$} & \multirow{2}{*}{ Economizer } & \multirow{2}{*}{$\begin{array}{c}\text { Heat } \\
\text { Recovery } \\
\text { Ventilation }\end{array}$} \\
\hline & & $\mathrm{m}^{3} / \mathrm{s} \cdot \mathrm{m}^{2}$ & $\mathrm{cfm} / \mathrm{ft}^{2}$ & & & \\
\hline $\begin{array}{l}\text { Existing } \\
\text { Stock }\end{array}$ & Reference & $2.68 \mathrm{E}-04$ & 0.060 & $\begin{array}{c}\text { Turk et al. } \\
(1989)\end{array}$ & $\begin{array}{l}\text { Varies by } \\
\text { building }\end{array}$ & $\begin{array}{l}\text { Varies by } \\
\text { building }\end{array}$ \\
\hline $\begin{array}{l}\text { Existing } \\
\text { Stock }\end{array}$ & $\begin{array}{l}\text { No Minimum } \\
\text { Mechanical } \\
\text { Ventilation }\end{array}$ & 2.68E-04 & 0.060 & $\begin{array}{l}\text { Zero unless } \\
\text { in economizer } \\
\text { mode }\end{array}$ & $\begin{array}{l}\text { Varies by } \\
\text { building }\end{array}$ & $\begin{array}{l}\text { Varies by } \\
\text { building }\end{array}$ \\
\hline $90.1-2004$ & Reference & 2.68E-04 & 0.060 & $\begin{array}{l}\text { As required } \\
\text { by } 62.1-2004\end{array}$ & $\begin{array}{l}\text { Where } \\
\text { required by } \\
90.1-2004\end{array}$ & $\begin{array}{c}\text { Where } \\
\text { required by } \\
90.1-2004\end{array}$ \\
\hline $90.1-2004$ & No Infiltration & 0.00 & 0.000 & $\begin{array}{l}\text { As required } \\
\text { by } 62.1-2004\end{array}$ & $\begin{array}{c}\text { Where } \\
\text { required by } \\
90.1-2004\end{array}$ & $\begin{array}{c}\text { Where } \\
\text { required by } \\
90.1-2004\end{array}$ \\
\hline $90.1-2004$ & $\begin{array}{c}\text { No } \\
\text { Mechanical } \\
\text { Ventilation }\end{array}$ & 2.68E-04 & 0.060 & 0.0 & No & $\begin{array}{c}\text { Not } \\
\text { Applicable }\end{array}$ \\
\hline $90.1-2004$ & $\begin{array}{l}\text { No Minimum } \\
\text { Mechanical } \\
\text { Ventilation }\end{array}$ & 2.68E-04 & 0.060 & $\begin{array}{l}\text { Zero unless } \\
\text { in economizer } \\
\text { mode }\end{array}$ & $\begin{array}{l}\text { Where } \\
\text { required by } \\
90.1-2004\end{array}$ & $\begin{array}{l}\text { Where } \\
\text { required by } \\
90.1-2004\end{array}$ \\
\hline $90.1-2004$ & $\begin{array}{c}\text { Half } \\
\text { Minimum } \\
\text { Mechanical } \\
\text { Ventilation }\end{array}$ & 2.68E-04 & 0.060 & $\begin{array}{l}\text { Half of } 62.1- \\
2004 \\
\text { requirements }\end{array}$ & $\begin{array}{l}\text { Where } \\
\text { required by } \\
90.1-2004\end{array}$ & $\begin{array}{l}\text { Where } \\
\text { required by } \\
90.1-2004\end{array}$ \\
\hline $90.1-2004$ & $\begin{array}{l}\text { Double } \\
\text { Minimum } \\
\text { Mechanical } \\
\text { Ventilation }\end{array}$ & 2.68E-04 & 0.060 & $\begin{array}{l}\text { Double } 62.1- \\
2004 \\
\text { requirements }\end{array}$ & $\begin{array}{l}\text { Where } \\
\text { required by } \\
90.1-2004\end{array}$ & $\begin{array}{l}\text { Where } \\
\text { required by } \\
90.1-2004\end{array}$ \\
\hline Max Tech & Reference & 6.69E-05 & 0.015 & $\begin{array}{l}\text { As required } \\
\text { by } 62.1-2004\end{array}$ & Yes & Yes \\
\hline Max Tech & $\begin{array}{l}\text { No Minimum } \\
\text { Mechanical } \\
\text { Ventilation }\end{array}$ & 6.69E-05 & 0.015 & $\begin{array}{l}\text { Zero unless } \\
\text { in economizer } \\
\text { mode }\end{array}$ & Yes & Yes \\
\hline
\end{tabular}




\section{Results and Discussion}

\section{$3.190 .1-2004$ Scenarios}

The 90.1-2004 Construction Group scenarios that were described in Section 2.2 were used to investigate the effects of outside air on new 2005 construction. The 90.1-2004 scenarios were derived from CBECS data with adjustments to meet 90.1-2004. The six scenarios that represent new construction include a reference scenario and five additional scenarios that modify the prescribed quantity of outside air in the reference scenario. We determined the effect of outside air by evaluating the difference between the 90.12004 reference scenario and another scenario that has a change in the outside air rates. Aggregate results for the entire commercial sector are shown in Table 3-1 through Table 3-5. Table 3-7 through Table 3-11 show a selection of the results based on climate zone and building subsector. Sector averages were determined by applying a weighting factor, based on the total floor area of similar buildings in the sector.

The average energy use intensities (EUIs) for the sector are shown in Table 3-1. EUIs are displayed as absolute quantities and as relative and percent changes compared to the reference scenario. Interpreting the relative quantities is generally straightforward; however, a brief explanation of the results is important. In most scenarios some outside air is removed from each model, so the relative values can be interpreted as the EUI associated with the quantity of outside air that is removed. For example, based on the relative decrease in EUI for the No Minimum Mechanical Ventilation Scenario, providing the minimum level of ventilation increases the average EUI for the commercial sector by $3.7 \mathrm{kBtu} / \mathrm{ft}^{2} \cdot \mathrm{yr}(42.0$ $\mathrm{MJ} / \mathrm{m}^{2} \cdot \mathrm{yr}$ ). The Double Minimum Mechanical Ventilation scenario is interpreted differently, because outside air is added to, instead of subtracted from, the reference set of models. Doubling the minimum ventilation increases the EUI by $8.7 \mathrm{kBtu} / \mathrm{ft}^{2} \cdot \mathrm{yr}\left(98.8 \mathrm{MJ} / \mathrm{m}^{2} \cdot \mathrm{yr}\right)$ compared to the reference.

The relative changes in total energy are informative; however, percentages, which are the relative differences normalized by the reference values, are a simpler measure of the effects attributed to outside air. Providing the minimum level of mechanical ventilation required by 90.1-2004 increases the total average EUI by $5.2 \%$, and supplying double the required ventilation rate increases the EUI by $12.4 \%$, compared to the reference model. Percentages from the full set of 90.1-2004 Construction Group scenarios are included in Table 3-1. 
Table 3-1 90.1-2004, Sector-Wide Average Total Site EUI

\begin{tabular}{|c|c|c|c|c|c|}
\hline \multirow{2}{*}{ Scenario } & \multicolumn{2}{|c|}{ Absolute } & \multicolumn{2}{|c|}{$\begin{array}{c}\text { Decrease Relative to } \\
\text { Reference }\end{array}$} & \multirow{2}{*}{$\begin{array}{c}\text { Percent } \\
\text { Decrease } \\
\text { Relative to } \\
\text { Reference } \\
\end{array}$} \\
\hline & $\left(\mathrm{kBtu} / \mathrm{ft}^{2} \cdot \mathrm{y}\right)$ & $\left(M J / m^{2} \cdot y\right)$ & $\left(k B t u / f^{2} \cdot y\right)$ & $\left(M J / m^{2} \cdot y\right)$ & \\
\hline Reference & 71.0 & 806.7 & - & - & - \\
\hline No Infiltration & 64.1 & 728.4 & 6.90 & 78.37 & $9.7 \%$ \\
\hline No Mechanical Ventilation & 71.1 & 807.3 & -0.05 & -0.56 & $-0.1 \%$ \\
\hline $\begin{array}{l}\text { No Minimum Mechanical } \\
\text { Ventilation }\end{array}$ & 67.3 & 764.9 & 3.69 & 41.86 & $5.2 \%$ \\
\hline $\begin{array}{l}\text { Half Minimum Mechanical } \\
\text { Ventilation }\end{array}$ & 68.4 & 777.4 & 2.59 & 29.37 & $3.7 \%$ \\
\hline $\begin{array}{l}\text { Double Minimum Mechanical } \\
\text { Ventilation }\end{array}$ & 79.8 & 905.7 & -8.72 & -98.99 & $-12.4 \%$ \\
\hline
\end{tabular}

The total ACH averaged across the sector are presented in Table 3-2. The format mirrors the method used to display results pertaining to the total EUI. The values are given as an absolute quantity, the decrease relative to the reference, and the percent decrease relative to the reference. The simulations predict that infiltration accounts for $31 \%$ of the total air change rate, and that minimum mechanical ventilation accounts for $53 \%$ of the total. The remaining balance of outside air is introduced by the HVAC system for economizing.

Figure 3-1 combines the data pertaining to total EUI and outside air change rate into a single illustration. In order from left to right, the series of connected points represent the scenarios with no minimum ventilation, half minimum ventilation, the reference quantity, and double ventilation. As discussed in the methodology, the equipment sizes are based on the reference models, except for the double ventilation scenario, where the equipment is resized to meet set point. The plot of EUI versus the total outside air change rate suggests a nonlinear relationship between EUI and the minimum mechanical ventilation rate. Interestingly, the data indicate that ventilation air has an increasing impact on energy use as the minimum ventilation rate increases. Admittedly, some of this nonlinearity is a result of resizing the double ventilation scenario; however, even neglecting that scenario there is a slight nonlinearity. Figure 3-1 also shows two outlying points that represent the scenarios with no mechanical ventilation and no infiltration. Compared to the 90.1-2004 reference point, these data points illustrate that significantly more energy is consumed by infiltration than by mechanical ventilation, even though mechanical ventilation introduces outside air at a higher rate. Simply put, a quantity of outside air provided by mechanical ventilation consumes less energy than the same quantity of outside air introduced through infiltration. We attribute this difference to the fact that outside air introduced by mechanical ventilation is engineered to take advantage of economizing and heat recovery in many of the 90.1-2004 Construction Group models. 
Table 3-2

90.1-2004, Sector-Wide Average ACH

\begin{tabular}{|l|c|c|c|}
\hline \multicolumn{1}{|c|}{ Scenario } & Absolute & $\begin{array}{c}\text { Decrease } \\
\text { Relative to } \\
\text { Reference } \\
(\mathbf{1} / \mathbf{h})\end{array}$ & $\begin{array}{c}\text { Percent Decrease } \\
\text { Relative to } \\
\text { Reference }\end{array}$ \\
\hline Reference & 0.80 & - & - \\
\hline No Infiltration & 0.55 & 0.24 & $31.25 \%$ \\
\hline No Mechanical Ventilation & 0.27 & 0.53 & $66.25 \%$ \\
\hline $\begin{array}{l}\text { No Minimum Mechanical } \\
\text { Ventilation }\end{array}$ & 0.38 & 0.42 & $52.50 \%$ \\
\hline $\begin{array}{l}\text { Half Minimum Mechanical } \\
\text { Ventilation }\end{array}$ & 0.58 & 0.22 & $27.50 \%$ \\
\hline $\begin{array}{l}\text { Double Minimum Mechanical } \\
\text { Ventilation }\end{array}$ & 1.19 & -0.40 & $-48.75 \%$ \\
\hline
\end{tabular}

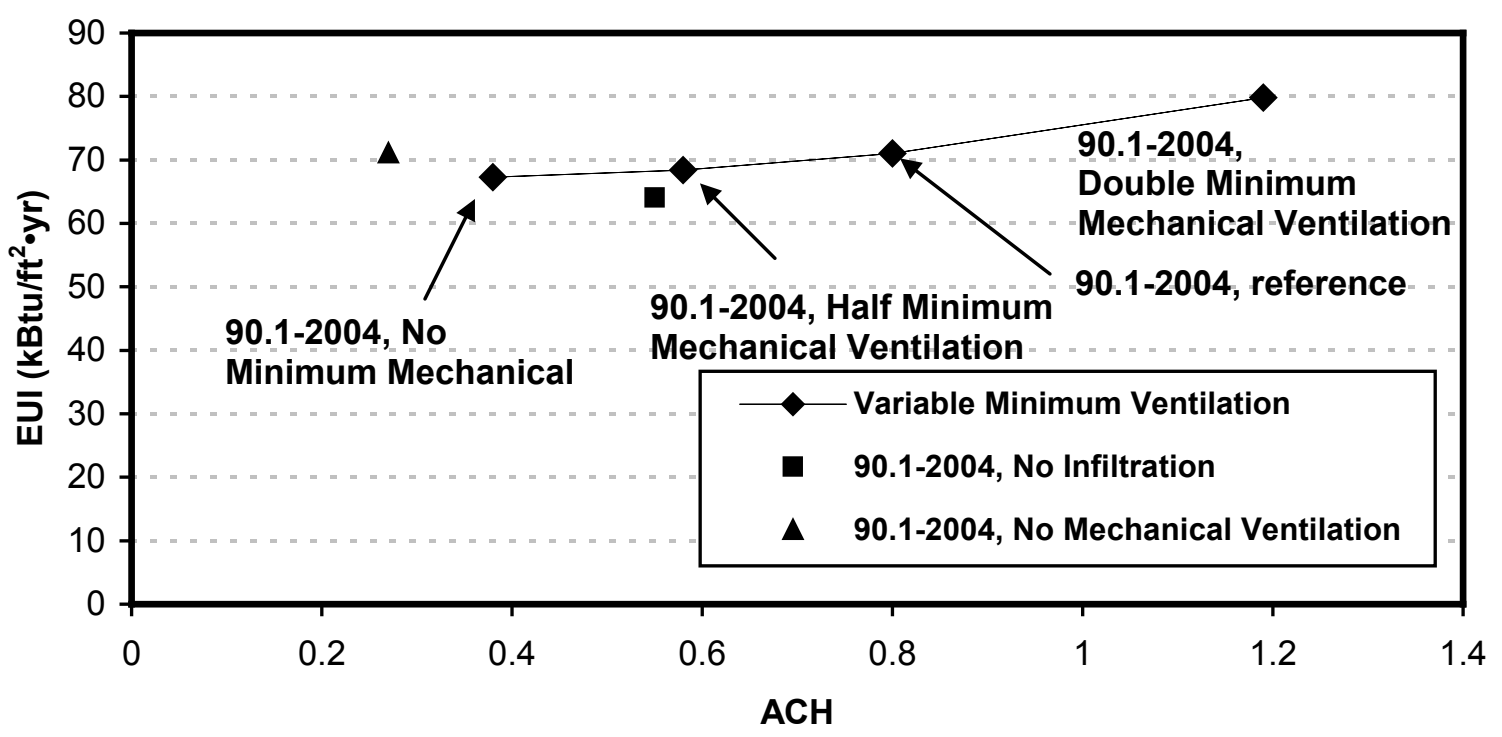

Figure 3-1 Sector-Wide Average EUI versus Total ACH for the 90.1-2004 Construction Group

Outside air has a different effect on the natural gas EUI (see Table 3-3) and the electricity EUI (see Table $3-4$ ), so these components are analyzed one at a time. Infiltration increases the natural gas EUI by $26.8 \%$ and the minimum mechanical ventilation increases the gas EUI 20.3\%. In contrast, infiltration increases the electricity EUI by only $0.9 \%$ and the minimum ventilation reduces the electricity EUI by $2.8 \%$. The varying effect of outside air on the gas and electric EUIs can be explained by associating gas energy with heating, and electrical energy with cooling. Under such an assumption the diminished effect of outside air on the electricity EUI can be attributed to economizing, or nearly free cooling that can be provided by 
outside air under some outdoor conditions. In other words, outside air can sometimes actually save cooling energy with economizing; however, rarely can outside air reduce heating energy. The effects of outside air on total annual electric energy and peak electric power are markedly different. In contrast to electric energy where outside air decreases the quantitative intensity, Table 3-5 shows that outside air increases the peak electric power in every scenario.

Table 3-3 90.1-2004, Sector-Wide Average Gas EUI

\begin{tabular}{|c|c|c|c|c|c|}
\hline \multirow{2}{*}{ Scenario } & \multicolumn{2}{|c|}{ Absolute } & \multicolumn{2}{|c|}{$\begin{array}{c}\text { Decrease Relative to } \\
\text { Reference }\end{array}$} & \multirow{2}{*}{$\begin{array}{c}\text { Percent } \\
\text { Decrease } \\
\text { Relative to } \\
\text { Reference } \\
\end{array}$} \\
\hline & $\left(\mathrm{kBtu} / \mathrm{ft}^{2} \cdot \mathrm{y}\right)$ & $\left(\mathrm{MJ} / \mathrm{m}^{2} \cdot \mathrm{y}\right)$ & $\left(k B t u / \mathrm{ft}^{2} \cdot y\right)$ & $\left(\mathrm{MJ} / \mathrm{m}^{2} \cdot \mathrm{y}\right)$ & \\
\hline Reference & 24.6 & 279.4 & - & - & - \\
\hline No Infiltration & 18.0 & 204.9 & 6.56 & 74.47 & $26.8 \%$ \\
\hline No Mechanical Ventilation & 21.3 & 241.9 & 3.30 & 37.50 & $13.4 \%$ \\
\hline $\begin{array}{l}\text { No Minimum Mechanical } \\
\text { Ventilation }\end{array}$ & 19.6 & 222.4 & 5.01 & 56.95 & $20.3 \%$ \\
\hline $\begin{array}{l}\text { Half Minimum Mechanical } \\
\text { Ventilation }\end{array}$ & 21.7 & 246.6 & 2.89 & 32.78 & $11.8 \%$ \\
\hline $\begin{array}{l}\text { Double Minimum Mechanical } \\
\text { Ventilation }\end{array}$ & 31.7 & 360.4 & -7.13 & -80.99 & $-28.9 \%$ \\
\hline
\end{tabular}


Table 3-4

90.1-2004, Sector-Wide Average Electricity Site EUI

\begin{tabular}{|c|c|c|c|c|c|}
\hline \multirow{2}{*}{ Scenario } & \multicolumn{2}{|c|}{ Absolute } & \multicolumn{2}{|c|}{$\begin{array}{c}\text { Decrease Relative to } \\
\text { Reference }\end{array}$} & \multirow{2}{*}{$\begin{array}{c}\text { Percent } \\
\text { Decrease } \\
\text { Relative to } \\
\text { Reference }\end{array}$} \\
\hline & $\left(\mathrm{kBtu} / \mathrm{ft}^{2} \cdot \mathrm{y}\right)$ & $\left(M J / m^{2} \cdot y\right)$ & $\left(\mathrm{kBtu} / \mathrm{ft}^{2} \cdot \mathrm{y}\right)$ & $\left(M J / m^{2} \cdot y\right)$ & \\
\hline Reference & 46.2 & 524.2 & - & - & - \\
\hline No Infiltration & 45.8 & 520.3 & 0.34 & 3.89 & $0.9 \%$ \\
\hline No Mechanical Ventilation & 49.5 & 562.3 & -3.35 & -38.06 & $-7.1 \%$ \\
\hline $\begin{array}{l}\text { No Minimum Mechanical } \\
\text { Ventilation }\end{array}$ & 47.5 & 539.3 & -1.33 & -15.09 & $-2.8 \%$ \\
\hline $\begin{array}{l}\text { Half Minimum Mechanical } \\
\text { Ventilation }\end{array}$ & 46.5 & 527.6 & -0.30 & -3.41 & $-0.6 \%$ \\
\hline $\begin{array}{l}\text { Double Minimum Mechanical } \\
\text { Ventilation }\end{array}$ & 47.7 & 542.2 & -1.58 & -18.00 & $-3.2 \%$ \\
\hline
\end{tabular}


Table 3-5

90.1-2004, Sector-Wide Average Peak Electric Power

\begin{tabular}{|l|c|c|c|c|c|}
\hline \multirow{2}{*}{ Scenario } & \multicolumn{2}{|c|}{ Absolute } & \multicolumn{2}{c|}{$\begin{array}{c}\text { Decrease Relative to } \\
\text { Reference }\end{array}$} & $\begin{array}{c}\text { Percent } \\
\text { Decrease } \\
\text { Relative to } \\
\text { Reference }\end{array}$ \\
\cline { 2 - 6 } & $\mathbf{( \mathbf { W } / \mathbf { f t } ^ { 2 } )}$ & $\mathbf{( \mathbf { W } / \mathbf { m } ^ { 2 } )}$ & $\mathbf{( W / \mathbf { f t } ^ { 2 } )}$ & $\mathbf{( \mathbf { W } / \mathbf { m } ^ { 2 } )}$ & - \\
\hline Reference & 5.12 & 55.07 & - & - & $7.03 \%$ \\
\hline No Infiltration & 4.76 & 51.27 & 0.35 & 3.80 & $6.06 \%$ \\
\hline No Mechanical Ventilation & 4.81 & 51.72 & 0.31 & 3.34 & $3.86 \%$ \\
\hline $\begin{array}{l}\text { No Minimum Mechanical } \\
\text { Ventilation }\end{array}$ & 4.82 & 51.84 & 0.30 & 3.23 & $3.32 \%$ \\
\hline $\begin{array}{l}\text { Half Minimum Mechanical } \\
\text { Ventilation }\end{array}$ & 4.95 & 53.26 & 0.17 & 1.81 & \\
\hline $\begin{array}{l}\text { Double Minimum Mechanical } \\
\text { Ventilation }\end{array}$ & 5.84 & 62.91 & -0.73 & -7.84 & $-14.06 \%$ \\
\hline
\end{tabular}

The previous results present several of the most relevant metrics regarding the effects of outside air. The sector average total EUI, ACH, gas EUI, electric EUI, and peak electric power are presented in absolute and relative terms and in SI and IP units. These data have been presented in tables to accommodate the large amount of information; however, it is difficult to see the relative nature of the results in tabular format. To address this difficulty, Figure 3-2 presents percent changes of the metrics in a chart to better illustrate the comparison between each 90.1-2004 scenario. 


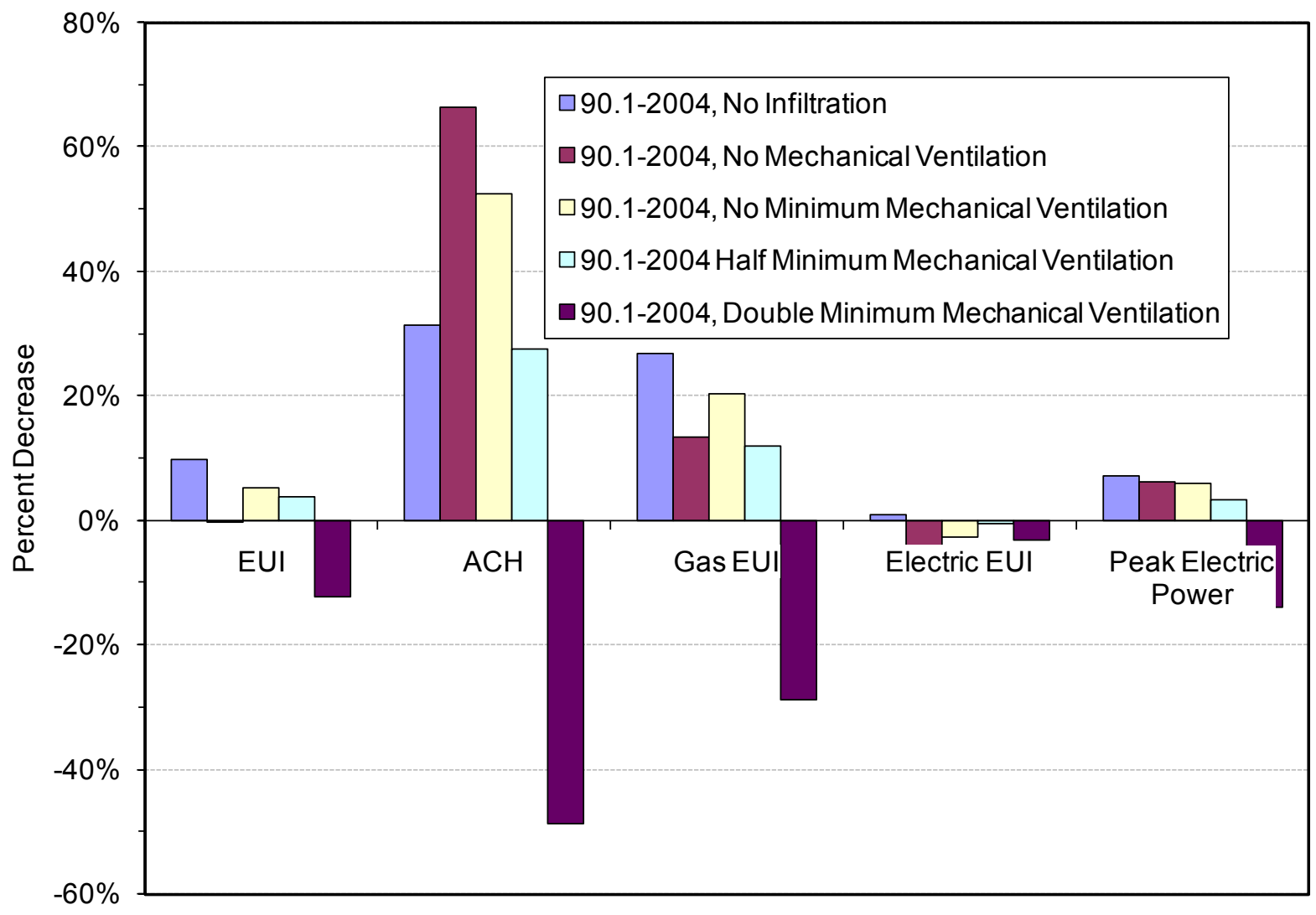

Figure 3-2 Summary of Percentage Decreases in Sector-Wide Averages

The U.S. commercial buildings sector is diverse, and the buildings vary by many factors, including geometry, type of construction, purpose, and climate zone. Sector averages provide a simple indicator of a particular metric such as total site EUI, but these averages do not show the entire picture. Figure 3-3 illustrates the variation of total site EUI in the commercial sector using a probability density function (PDF) of the relative change in total EUI. Most buildings have a change in EUI near the average for the sector $\left(3.7 \mathrm{kBtu} / \mathrm{ft}^{2} \cdot \mathrm{yr}\right)\left(42.0 \mathrm{MJ} / \mathrm{m}^{2} \cdot \mathrm{y}\right)$, but some differ significantly. For some buildings, the minimum ventilation actually results in energy savings, presumably due to uncontrolled economizing due to the minimum outside air requirement. Although PDFs are not given for all metrics, we expect similar variation across the sector for the other metrics that have been shown as sector averages. 


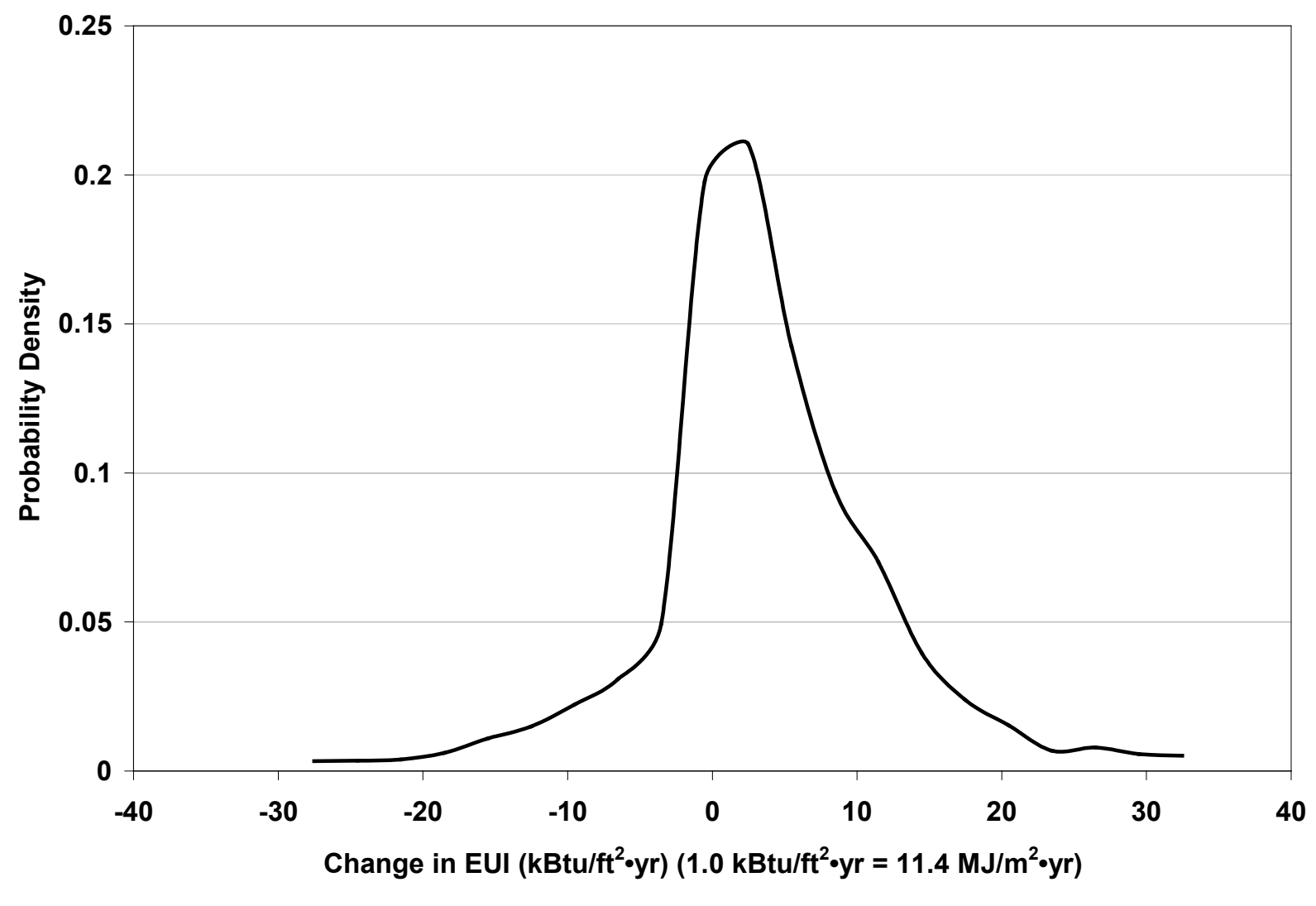

Figure 3-3 PDF of Change in Sector Average EUI for 90.1-2004, No Minimum Mechanical Ventilation

The PDF of the change in total EUI due to the minimum ventilation indicates a significant variation in this quantity across the sector. A significant portion of the variation is believed to be associated with the building subsector and climate zone. To address the possibility that climate and subsector are important variables, select results are presented in a tabular format that shows the effect of minimum ventilation based on climate zone and building subsector. Table 3-7 through Table 3-11 show the percent change in total EUI, ACH, gas EUI, electricity EUI, and peak electric demand, respectively, when the minimum mechanical ventilation is set to zero.

The detailed tables based on climate zone and subsector should be used cautiously, because sometimes only a few buildings are associated with each table entry. As a result, a single building simulation can have a significant impact on the results. The exact number of buildings in the CBECS survey is broken down by climate zone and subsector in Table 3-6. 
Table 3-6 Number of Models by Subsectors and Climate Zones

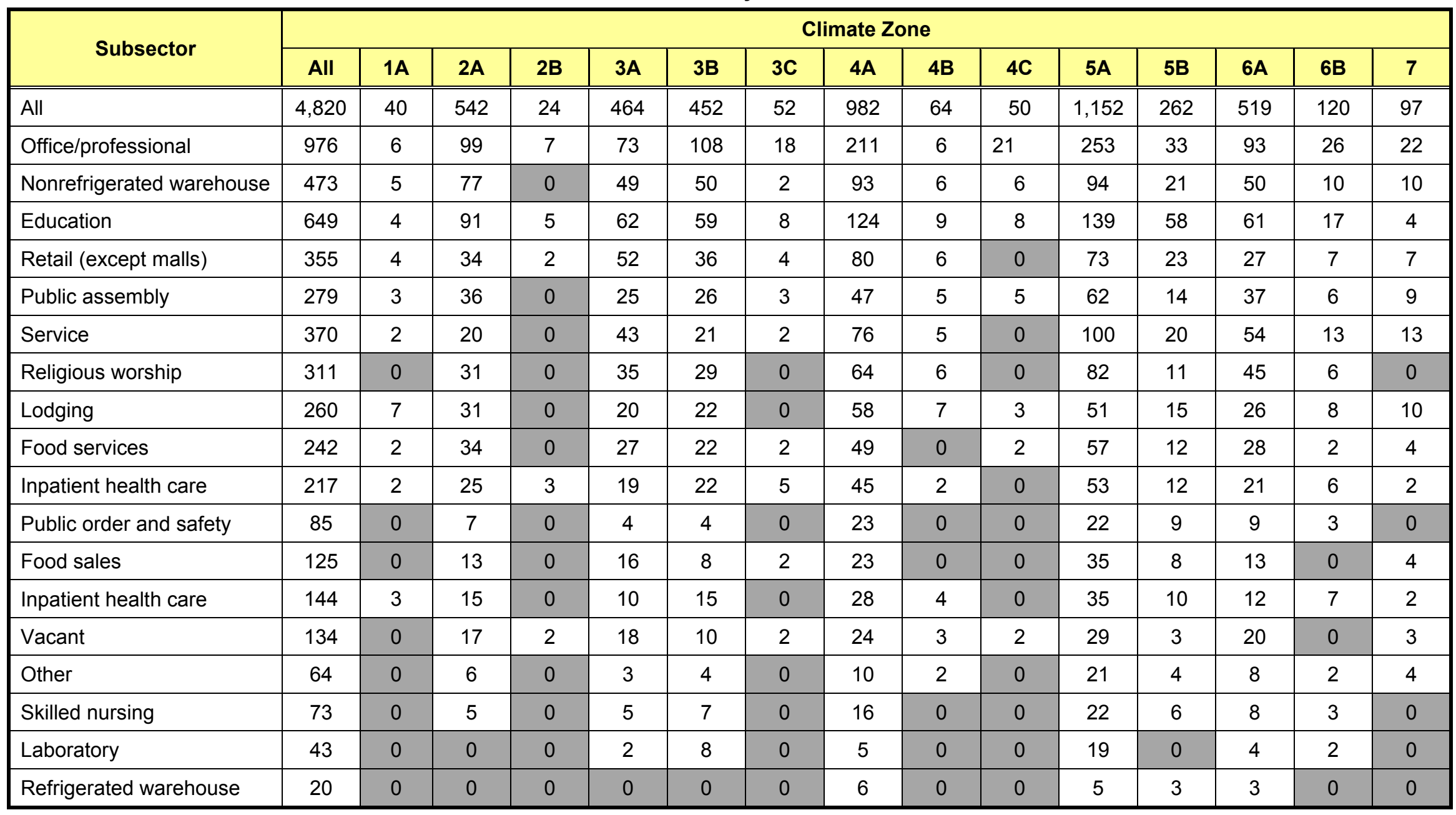


Table 3-7

90.1-2004, No Minimum Mechanical Ventilation Scenario, Percent Change in EUI by Climate Zone and Subsector

\begin{tabular}{|c|c|c|c|c|c|c|c|c|c|c|c|c|c|c|c|}
\hline \multirow{2}{*}{ Subsector } & \multicolumn{15}{|c|}{ Climate Zone } \\
\hline & All & $1 \mathrm{~A}$ & $2 A$ & 2B & $3 A$ & 3B & $3 C$ & $4 A$ & 4B & $4 C$ & $5 A$ & $5 B$ & $6 A$ & $6 \mathrm{~B}$ & 7 \\
\hline All & 5.2 & 2.8 & -3.7 & -2.2 & -2.3 & 0.9 & 1.2 & 1.2 & 9.5 & 6.4 & 9.6 & 9.4 & 15.1 & 19.1 & 15.9 \\
\hline Office/professional & 2.1 & 4.2 & -1.4 & -0.7 & 1.6 & 0.0 & -0.8 & -0.2 & 2.4 & 4.4 & 4.3 & 4.0 & 5.9 & 9.0 & 4.3 \\
\hline Nonrefrigerated warehouse & 6.9 & 3.5 & -5.0 & & 5.3 & 5.6 & 1.0 & 6.4 & 7.5 & 7.6 & 10.1 & 10.0 & 9.8 & 11.0 & 12.5 \\
\hline Education & 7.7 & -10.6 & -14.4 & 7.0 & -3.2 & 3.7 & 11.7 & -3.5 & 5.4 & 12.9 & 19.7 & 17.8 & 27.7 & 37.0 & 30.8 \\
\hline Retail (excluding mall) & 7.4 & 5.2 & -3.9 & 5.0 & 2.4 & -0.4 & 2.5 & 4.3 & 1.9 & & 15.2 & 12.3 & 17.0 & 16.8 & 23.5 \\
\hline Public assembly & 6.9 & -0.6 & -0.1 & & -4.0 & 1.1 & 1.1 & 0.7 & 12.7 & 10.3 & 15.4 & 6.4 & 15.7 & 3.8 & 15.4 \\
\hline Service & 16.9 & -9.2 & -5.1 & & 9.4 & 9.3 & -2.0 & 10.1 & 11.2 & & 19.3 & 19.9 & 30.0 & 28.7 & 29.1 \\
\hline Religious worship & 12.6 & & -7.5 & & 8.4 & 5.4 & & 12.4 & 18.5 & & 17.3 & 13.3 & 17.1 & 19.8 & \\
\hline Lodging & 11.2 & 1.9 & 4.4 & & 5.0 & 3.5 & & 11.6 & 13.5 & 6.9 & 14.9 & 10.0 & 16.4 & 17.5 & 20.8 \\
\hline Food services & -0.2 & 3.0 & -1.9 & & -1.8 & -1.2 & -0.7 & -2.3 & & -1.1 & 1.2 & 0.1 & 4.8 & 7.0 & 7.7 \\
\hline Health care (inpatient) & -2.7 & 2.2 & 3.6 & -2.4 & -24.3 & -2.2 & -3.1 & -3.3 & -0.7 & & 3.3 & 3.8 & 17.9 & 21.9 & -6.3 \\
\hline Public order and safety & 2.2 & & 1.3 & & 3.9 & 1.3 & & -12 & & & 5.0 & 0.3 & 7.3 & -1.6 & \\
\hline Food sales & 1.2 & & -0.1 & & -2.0 & 0.4 & 0.0 & -1.7 & & & 2.8 & 3.3 & 6.6 & & 4.0 \\
\hline Health care (outpatient) & 8.1 & 12.2 & -15.3 & & -12.4 & -14.4 & & 5.8 & 18.8 & & 15.3 & 11.9 & 27.2 & 20.0 & 40.3 \\
\hline Vacant & 12.1 & & 18.6 & -0.8 & 9.1 & 8.2 & 2.8 & 4.9 & 13.0 & 11.3 & 17.7 & 7.2 & 12.9 & & 18.3 \\
\hline Other & 3.5 & & -3.2 & & -1.8 & 1.0 & & -0.5 & 8.2 & & 5.9 & 5.8 & 8.1 & 11.6 & 10.2 \\
\hline Skilled nursing & -0.6 & & -4.3 & & -18.7 & -1.1 & & -28.3 & & & 7.7 & 13.3 & 24.5 & 27.4 & \\
\hline Laboratory & -1.4 & & & & -0.5 & -4.4 & & -1.4 & & & -1.7 & & 0.1 & 0.4 & \\
\hline Refrigerated warehouse & 4.4 & & & & & & & 1.7 & & & 8.4 & 7.2 & 8.4 & & \\
\hline
\end{tabular}


Table 3-8 90.1-2004, No Minimum Mechanical Ventilation, Percent Change in ACH by Climate Zone and Subsector

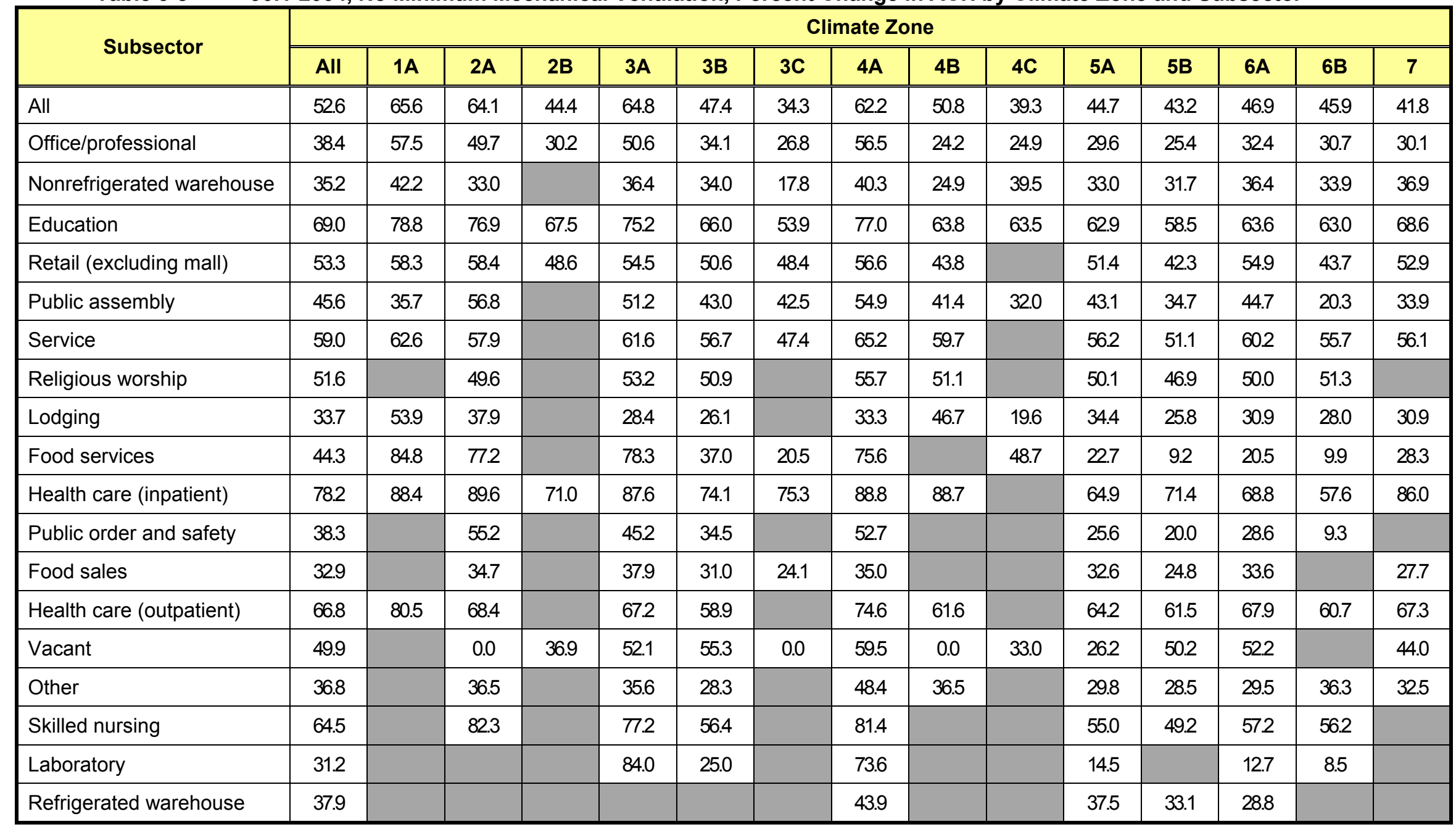


Table 3-9 90.1-2004, No Minimum Mechanical Ventilation, Percent Change in Gas EUI by Climate Zone and Subsector

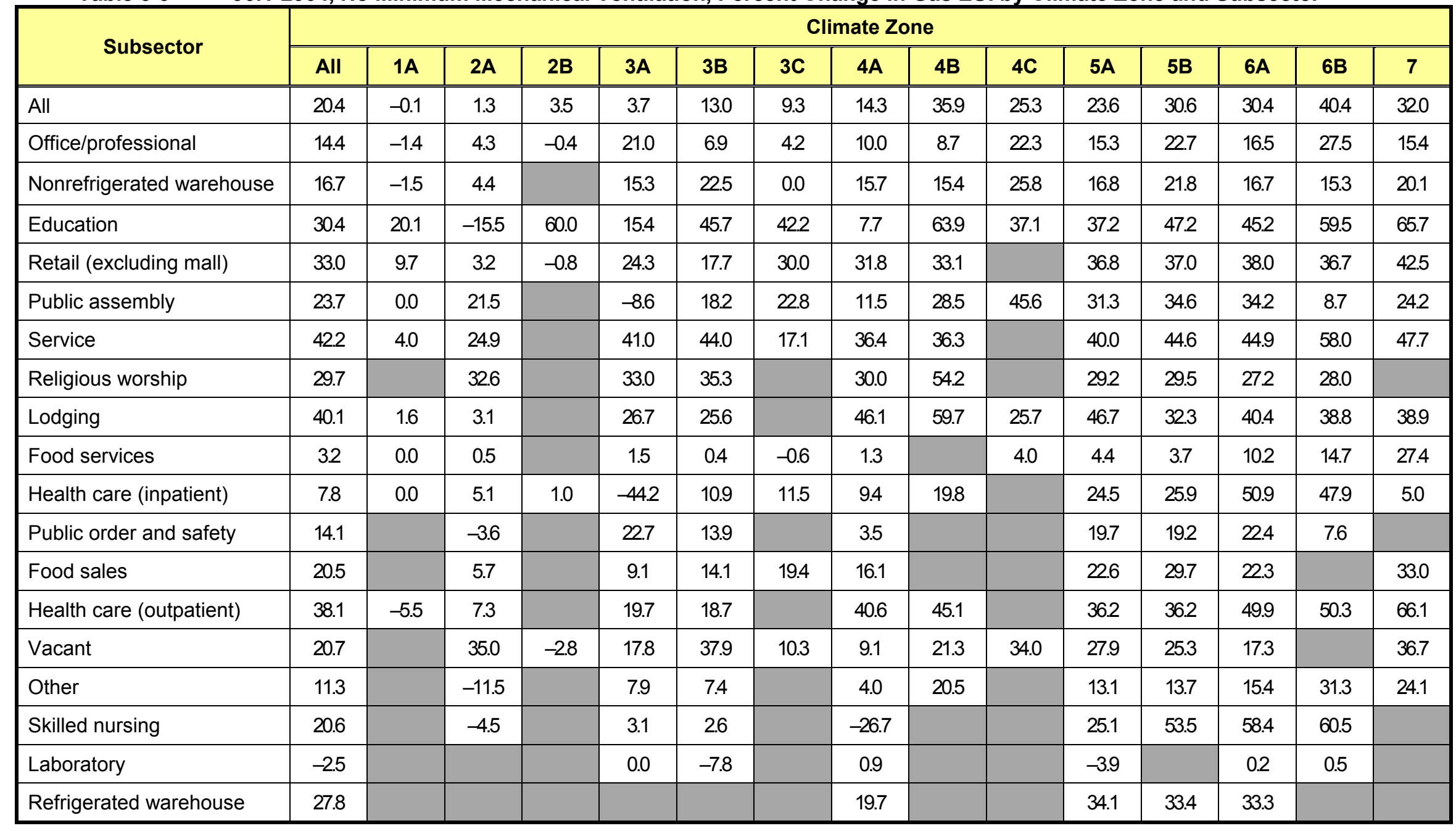


Table 3-10 90.1-2004, No Minimum Mechanical Ventilation, Percent Change in Electricity EUl by Climate Zone and Subsector

\begin{tabular}{|c|c|c|c|c|c|c|c|c|c|c|c|c|c|c|c|}
\hline \multirow{2}{*}{ Subsector } & \multicolumn{15}{|c|}{ Climate Zone } \\
\hline & All & $1 \mathrm{~A}$ & $2 A$ & 2B & $3 A$ & 3B & $3 C$ & $4 \mathrm{~A}$ & 4B & 4C & $5 \mathrm{~A}$ & $5 B$ & 6A & 6B & 7 \\
\hline All & -2.9 & 3.4 & -4.7 & -2.8 & -4.7 & -3.2 & -2.7 & -4.8 & -2.3 & -1.2 & -1.0 & -1.0 & -0.7 & -0.9 & 1.2 \\
\hline Office/professional & -1.0 & 4.6 & -1.7 & -0.7 & -1.1 & -0.6 & -1.6 & -2.2 & 0.4 & -0.5 & 0.1 & 0.0 & -0.1 & -1.0 & -2.2 \\
\hline Nonrefrigerated warehouse & -1.5 & 3.6 & -6.5 & & -1.1 & 0.8 & 1.0 & -1.9 & 0.1 & -0.5 & 0.0 & 1.6 & -0.8 & 0.8 & -0.7 \\
\hline Education & -6.6 & -10.9 & -14.3 & 0.0 & -10.1 & -8.7 & -5.5 & -10.5 & -15.6 & -2.7 & 1.8 & 0.0 & 2.7 & -0.5 & -0.3 \\
\hline Retail (excluding mall) & -3.0 & 5.2 & -4.4 & 6.0 & -4.7 & -4.1 & 0.5 & -5.1 & -5.2 & & 0.3 & -1.0 & -0.8 & 0.2 & -5.1 \\
\hline Public assembly & -2.2 & -0.6 & -1.8 & & -2.4 & -3.2 & -4.4 & -4.9 & -1.3 & -1.3 & -0.2 & -3.1 & -2.9 & -0.4 & 6.7 \\
\hline Service & -2.6 & -10.0 & -8.4 & & -2.3 & -4.6 & -7.3 & -3.6 & 1.0 & & -1.3 & 0.5 & -0.9 & 0.6 & 1.6 \\
\hline Religious worship & -2.3 & & -10.9 & & -2.6 & -1.3 & & -2.2 & 0.1 & & 0.1 & 1.4 & 0.5 & 0.4 & \\
\hline Lodging & 1.4 & 2.0 & 4.5 & & 0.1 & -1.8 & & 0.1 & -0.4 & -0.1 & 1.5 & -0.4 & 3.6 & -1.2 & 10.1 \\
\hline Food services & -2.9 & 5.3 & -3.1 & & -3.7 & -2.9 & -1.0 & -5.0 & & -8.3 & -1.8 & -2.6 & -0.6 & -2.1 & -4.3 \\
\hline Health care (inpatient) & -9.1 & 3.0 & 3.1 & -3.8 & -12.1 & -8.3 & -12.0 & -10.1 & -9.4 & & -11.0 & -10.3 & -10.7 & -7.1 & -16.0 \\
\hline Public order and safety & -1.3 & & 1.7 & & -1.9 & -0.2 & & -2.5 & & & -0.7 & -3.5 & -0.9 & -3.4 & \\
\hline Food sales & -2.1 & & -0.5 & & -2.9 & -1.3 & -3.0 & -3.8 & & & -2.2 & -1.4 & -1.1 & & -1.3 \\
\hline Health care (outpatient) & -8.4 & 14.0 & -17.3 & & -19.0 & -22.1 & & -11.6 & 1.3 & & -4.1 & 1.4 & 0.5 & -5.8 & -2.5 \\
\hline Vacant & -0.1 & & 8.2 & -0.1 & -1.6 & -6.9 & -8.1 & -1.0 & 1.7 & 2.5 & 0.8 & 3.4 & 0.6 & & -1.3 \\
\hline Other & -1.0 & & -1.5 & & -2.7 & 0.6 & & -2.3 & 1.0 & & -0.3 & 0.3 & 0.5 & -0.2 & 1.5 \\
\hline Skilled nursing & -11.8 & & -4.2 & & -21.7 & -2.3 & & -29.3 & & & -5.4 & -7.4 & -5.5 & -1.7 & \\
\hline Laboratory & -0.7 & & & & -0.8 & -1.7 & & -2.9 & & & 0.1 & & 0.1 & 0.3 & \\
\hline Refrigerated warehouse & 0.0 & & & & & & & -0.5 & & & 0.8 & 0.4 & -0.4 & & \\
\hline
\end{tabular}


Table 3-11 90.1-2004, No Minimum Mechanical Ventilation, Percent Change in Peak Electrical Power by Climate Zone and Subsector

\begin{tabular}{|c|c|c|c|c|c|c|c|c|c|c|c|c|c|c|c|}
\hline \multirow{2}{*}{ Subsector } & \multicolumn{15}{|c|}{ Climate Zone } \\
\hline & All & $1 \mathrm{~A}$ & $2 A$ & 2B & 3A & 3B & $3 C$ & 4A & 4B & 4C & $5 A$ & 5B & $6 A$ & $6 B$ & 7 \\
\hline All & 5.9 & 5.4 & 3.9 & 1.6 & 7.3 & 4.1 & 3.7 & 6.0 & 9.3 & 4.3 & 5.8 & 6.9 & 7.6 & 52 & 9.2 \\
\hline Office/professional & 3.1 & 2.1 & 2.5 & 0.3 & 5.1 & 1.8 & 3.3 & 3.3 & 3.3 & 3.5 & 3.1 & 2.1 & 3.5 & 3.4 & 4.0 \\
\hline Nonrefrigerated warehouse & 4.9 & 1.6 & 3.2 & & 3.0 & 4.4 & 8.0 & 5.9 & 4.6 & 3.8 & 4.8 & 8.9 & 8.2 & 32 & 6.1 \\
\hline Education & 9.7 & 1.8 & 5.4 & 9.1 & 15.0 & 4.7 & 3.0 & 10.9 & 16.5 & 5.0 & 9.6 & 11.8 & 10.2 & 5.3 & 11.9 \\
\hline Retail (excluding mall) & 4.4 & 0.2 & 4.3 & 6.8 & 3.8 & 4.4 & 10.4 & 3.4 & 5.2 & & 5.4 & 3.6 & 7.3 & 2.7 & 8.6 \\
\hline Public assembly & 4.3 & 0.0 & 1.9 & & 4.9 & 3.4 & 3.4 & 2.9 & 3.7 & 4.4 & 5.1 & 2.2 & 7.4 & 2.4 & 9.0 \\
\hline Service & 6.5 & 0.2 & 1.4 & & 6.1 & 6.3 & -0.6 & 5.9 & 8.8 & & 6.0 & 5.8 & 11.2 & 10.5 & 13.4 \\
\hline Religious worship & 5.0 & & 1.2 & & 3.5 & 6.7 & & 4.0 & 6.2 & & 7.0 & 9.9 & 5.5 & 3.2 & \\
\hline Lodging & 14.5 & 14.0 & 9.8 & & 14.2 & 9.4 & & 16.3 & 12.6 & 21.2 & 16.1 & 9.6 & 18.6 & 7.4 & 19.2 \\
\hline Food services & 2.6 & 8.8 & 2.1 & & 3.9 & 3.1 & 1.3 & 2.1 & & 2.3 & 3.0 & 0.9 & 3.1 & -0.6 & 1.5 \\
\hline Health care (inpatient) & 11.6 & 9.6 & 21.7 & 8.9 & 11.5 & 5.9 & 1.6 & 17.6 & 6.0 & & 8.0 & 3.1 & 9.3 & 3.0 & 7.0 \\
\hline Public order and safety & 2.9 & & 2.7 & & 3.7 & 2.3 & & 3.2 & & & 3.3 & 0.9 & 3.5 & 0.9 & \\
\hline Food sales & 1.4 & & 1.5 & & 1.8 & 1.2 & 0.0 & 0.8 & & & 1.4 & 1.4 & 2.2 & & 2.9 \\
\hline Health care (outpatient) & 6.6 & 14.2 & 0.2 & & 0.5 & -1.3 & & 6.3 & 12.5 & & 8.8 & 17.8 & 11.6 & 4.3 & 13.6 \\
\hline Vacant & 7.5 & & 9.6 & 2.6 & 9.7 & 11.5 & 7.8 & 4.3 & 4.9 & 9.2 & 8.7 & 17.5 & 6.4 & & 8.3 \\
\hline Other & 4.4 & & 2.9 & & 5.5 & 4.4 & & 4.6 & 4.0 & & 5.3 & 1.9 & 3.5 & 3.7 & 4.5 \\
\hline Skilled nursing & 12.7 & & 15.3 & & 10.4 & 7.7 & & 9.6 & & & 9.7 & 11.6 & 19.9 & 5.7 & \\
\hline Laboratory & 3.4 & & & & 6.0 & 0.0 & & 5.3 & & & 1.8 & & 2.6 & 4.5 & \\
\hline Refrigerated warehouse & 7.8 & & & & & & & 7.5 & & & 7.4 & 5.1 & 6.7 & & \\
\hline
\end{tabular}




\subsection{Existing Stock}

The results pertaining to new construction will help us to assess the effect of outside air in the future; however, an assessment of the existing stock of buildings is needed to determine the role of outside air in the sector today. The Existing Stock Construction Group models are composed of a reference scenario and one other scenario where the minimum mechanical ventilation is set to zero. The effects of outside air on the aggregate of the commercial sector as it is constructed today are shown in Table 3-12 through Table 3-16.

The trends pertaining to the existing stock are generally similar to those observed for the 90.1-2004 Construction Group scenarios. Table 3-12 shows that the average total EUI across the sector is increased by $6.6 \%$ because of the minimum ventilation rate. The results of the 90.1-2004 and Existing Stock construction group scenarios indicate that the required ventilation has a greater impact on the Existing Stock. We suggest that this difference is a result of the improved outside air management of the newer buildings, specifically, the use of economizers and heat recovery systems in the 90.1-2004 scenarios. The PDF in Figure 3-4 shows significant variation across the sector, but to a lesser extent for the Existing Stock Construction Group models.

Table 3-12 Existing Stock, Sector-Wide Average Total Site EUI

\begin{tabular}{|c|c|c|c|c|c|}
\hline \multirow[t]{2}{*}{ Scenario } & \multicolumn{2}{|c|}{ Absolute } & \multicolumn{2}{|c|}{$\begin{array}{c}\text { Decrease Relative to } \\
\text { Reference }\end{array}$} & \multirow{2}{*}{$\begin{array}{l}\text { Percent Decrease } \\
\text { Relative to } \\
\text { Reference }\end{array}$} \\
\hline & $\left(k B t u / f^{2} \cdot y\right)$ & $\left(\mathrm{MJ} / \mathrm{m}^{2} \cdot \mathrm{y}\right)$ & $\left(\mathrm{kBtu} / \mathrm{ft}^{2} \cdot \mathrm{y}\right)$ & $\left(\mathrm{MJ} / \mathrm{m}^{2} \cdot \mathrm{y}\right)$ & \\
\hline Reference & 74.2 & 842.6 & - & - & - \\
\hline $\begin{array}{l}\text { No Minimum Mechanical } \\
\text { Ventilation }\end{array}$ & 69.3 & 787.0 & 4.90 & 55.64 & 6.6 \\
\hline
\end{tabular}




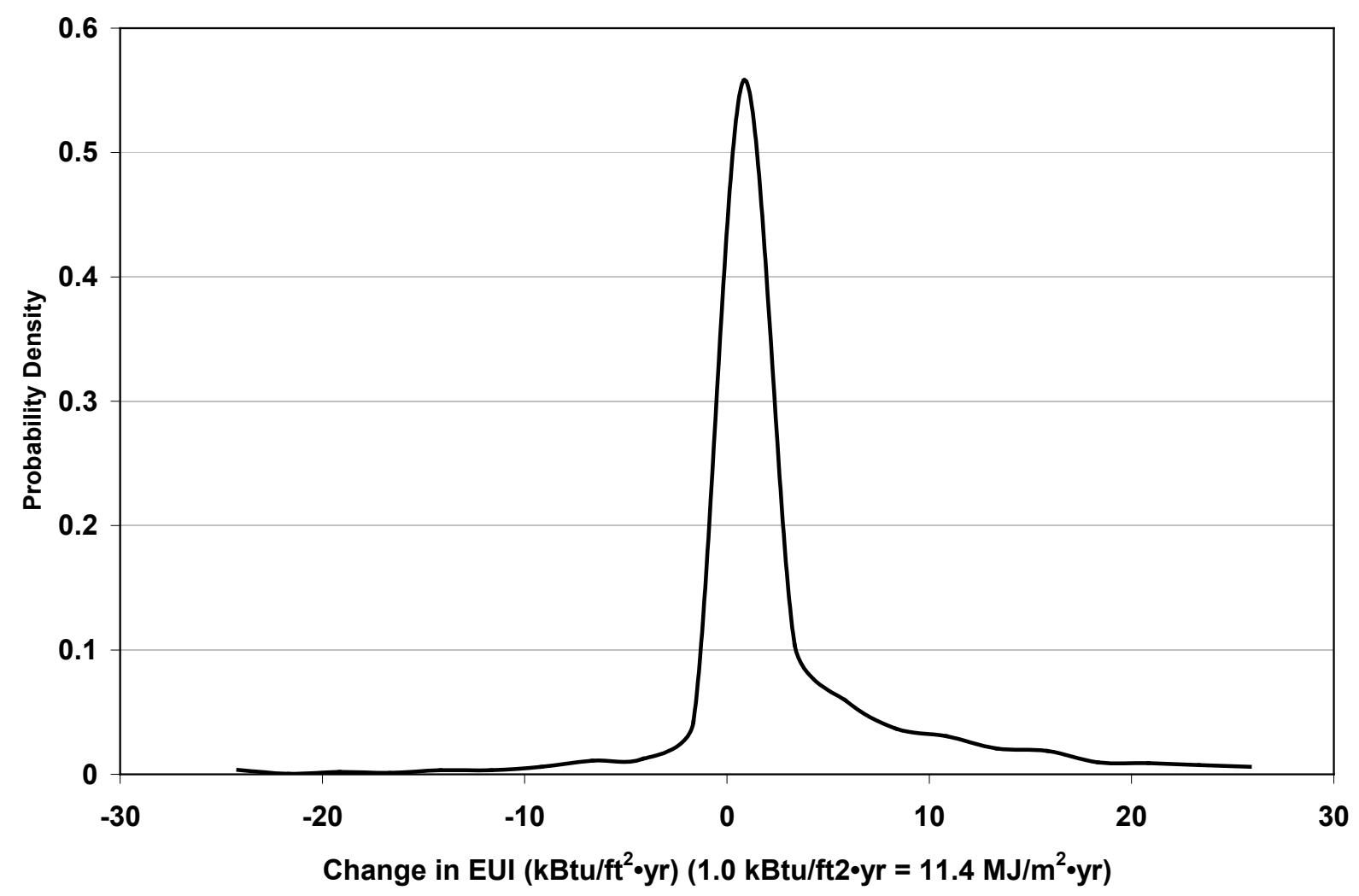

Figure 3-4 PDF of Change in Sector Average EUI for Existing Stock, No Minimum Mechanical Ventilation

The air change rate for the Existing Stock Construction Group is slightly lower than for the 90.1-2004 Construction Group buildings (see Table 3-13). Again the gas EUI (Table 3-14) is affected more by the required ventilation than by the electricity EUI. Table 3-15 shows that the electricity EUI is unaffected by the required ventilation, although the peak electric power is increased by almost $6 \%$.

Table 3-13 Existing Stock, Sector-Wide Average ACH

\begin{tabular}{|l|c|c|c|}
\hline \multicolumn{1}{|c|}{ Scenario } & $\begin{array}{c}\text { Absolute } \\
(\mathbf{1 / h})\end{array}$ & $\begin{array}{c}\text { Decrease } \\
\text { Relative to } \\
\text { Reference (1/h) }\end{array}$ & $\begin{array}{c}\text { Percent Decrease } \\
\text { Relative to } \\
\text { Reference }\end{array}$ \\
\hline \hline Reference & 0.76 & - & - \\
\hline $\begin{array}{l}\text { No Minimum Mechanical } \\
\text { Ventilation }\end{array}$ & 0.35 & 0.41 & $53.95 \%$ \\
\hline
\end{tabular}


Table 3-14 Existing Stock, Sector-Wide Average Gas EUI

\begin{tabular}{|c|c|c|c|c|c|}
\hline \multirow{2}{*}{ Scenario } & \multicolumn{2}{|c|}{ Absolute } & \multicolumn{2}{|c|}{$\begin{array}{c}\text { Decrease Relative to } \\
\text { Reference }\end{array}$} & \multirow{2}{*}{$\begin{array}{c}\text { Percent } \\
\text { Decrease } \\
\text { Relative to } \\
\text { Reference }\end{array}$} \\
\hline & $\left(\mathrm{kBtu} / \mathrm{ft}^{2} \cdot \mathrm{yr}\right)$ & $\left(\mathrm{MJ} / \mathrm{m}^{2} \cdot \mathrm{yr}\right)$ & $\left(\mathrm{kBtu} / \mathrm{ft}^{2} \cdot \mathrm{yr}\right)$ & $\left(\mathrm{MJ} / \mathrm{m}^{2} \cdot \mathrm{yr}\right)$ & \\
\hline Reference & 21.0 & 238.5 & - & - & - \\
\hline $\begin{array}{l}\text { No Minimum Mechanical } \\
\text { Ventilation }\end{array}$ & 16.5 & 187.4 & 4.5 & 51.1 & $21.4 \%$ \\
\hline
\end{tabular}

Table 3-15 Existing Stock, Sector-Wide Average Electricity EUI

\begin{tabular}{|c|c|c|c|c|c|}
\hline \multirow{2}{*}{ Scenario } & \multicolumn{2}{|c|}{ Absolute } & \multicolumn{2}{|c|}{$\begin{array}{c}\text { Decrease Relative to } \\
\text { Reference }\end{array}$} & \multirow{2}{*}{$\begin{array}{c}\text { Percent } \\
\text { Decrease } \\
\text { Relative to } \\
\text { Reference } \\
\end{array}$} \\
\hline & $\left(\mathrm{kBtu} / \mathrm{ft}^{2} \cdot \mathrm{yr}\right)$ & $\left(\mathrm{MJ} / \mathrm{m}^{2} \cdot \mathrm{yr}\right)$ & $\left(\mathrm{kBtu} / \mathrm{ft}^{2} \cdot \mathrm{yr}\right)$ & $\left(\mathrm{MJ} / \mathrm{m}^{2} \cdot \mathrm{yr}\right)$ & \\
\hline Reference & 50.8 & 576.9 & - & - & - \\
\hline $\begin{array}{l}\text { No Minimum Mechanical } \\
\text { Ventilation }\end{array}$ & 50.8 & 576.9 & 0 & 0 & 0 \\
\hline
\end{tabular}

Table 3-16 Existing Stock, Sector-Wide Average Peak Electric Power

\begin{tabular}{|c|c|c|c|c|c|}
\hline \multirow{2}{*}{ Scenario } & \multicolumn{2}{|c|}{ Absolute } & \multicolumn{2}{|c|}{$\begin{array}{c}\text { Decrease Relative to } \\
\text { Reference }\end{array}$} & \multirow{2}{*}{$\begin{array}{c}\text { Percent } \\
\text { Decrease } \\
\text { Relative to } \\
\text { Reference } \\
\end{array}$} \\
\hline & $\left(\mathrm{kBtu} / \mathrm{ft}^{2} \cdot \mathrm{yr}\right)$ & $\left(\mathrm{MJ} / \mathrm{m}^{2} \cdot \mathrm{yr}\right)$ & $\left(k B t u / \mathrm{ft}^{2} \cdot \mathrm{yr}\right)$ & $\left(\mathrm{MJ} / \mathrm{m}^{2} \cdot \mathrm{yr}\right)$ & \\
\hline Reference & 5.25 & 56.47 & - & - & - \\
\hline $\begin{array}{l}\text { No Minimum Mechanical } \\
\text { Ventilation }\end{array}$ & 4.94 & 53.13 & 0.31 & 3.34 & $5.91 \%$ \\
\hline
\end{tabular}

The results of the previous five tables are more thoroughly presented, by climate zone and subsector, in Table 3-17 through Table 3-21. 
Table 3-17 Existing Stock, No Minimum Mechanical Ventilation, Total EUI Percent Change for Climate Zone and Subsector

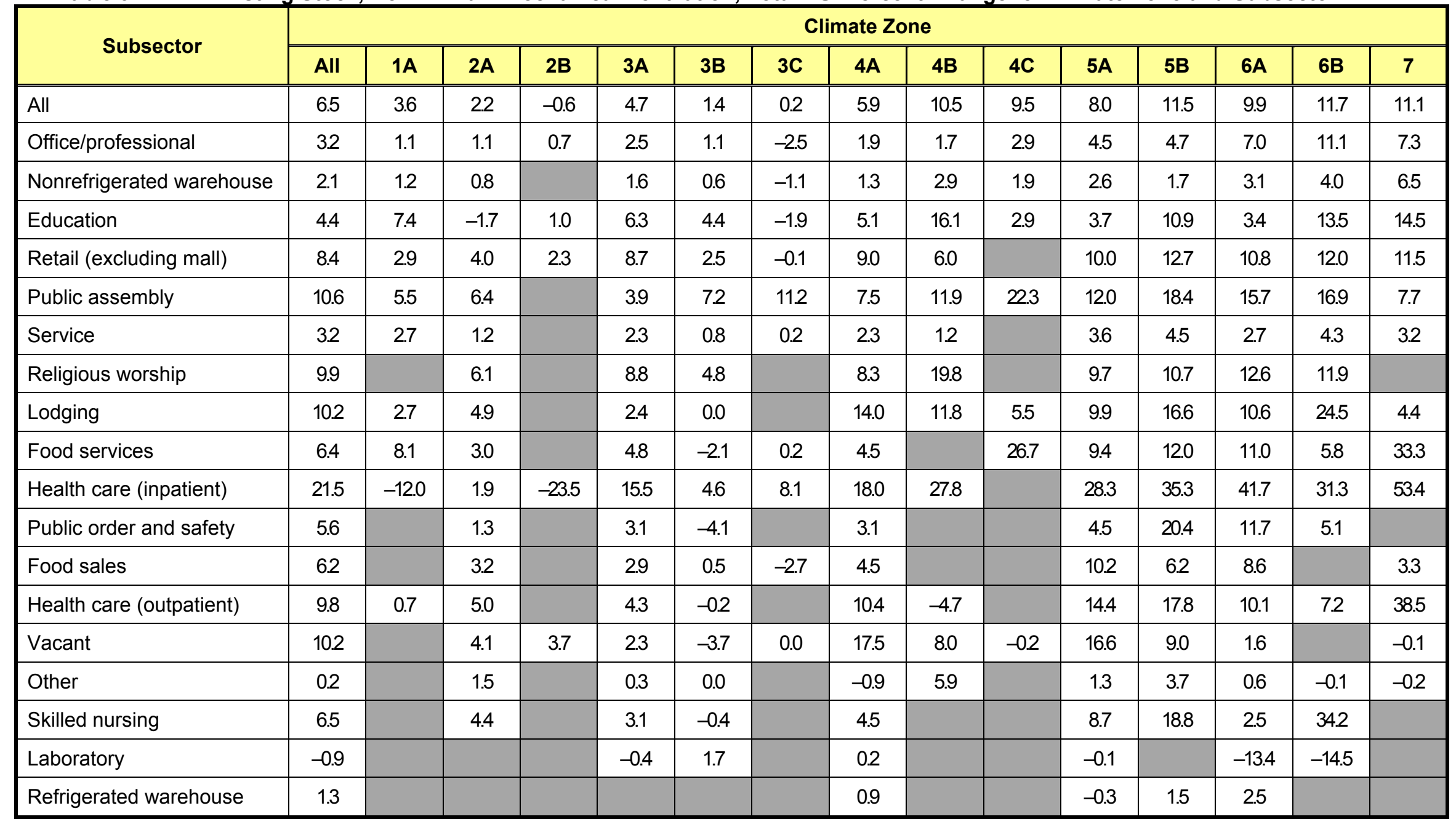


Table 3-18

Existing Stock, No Minimum Mechanical Ventilation, ACH Percent Change for Climate Zone and Subsector

\begin{tabular}{|c|c|c|c|c|c|c|c|c|c|c|c|c|c|c|c|}
\hline \multirow{2}{*}{ Subsector } & \multicolumn{15}{|c|}{ Climate Zone } \\
\hline & All & 1A & $2 A$ & 2B & 3A & 3B & $3 \mathrm{C}$ & 4A & 4B & 4C & $5 A$ & 5B & $6 A$ & 6B & 7 \\
\hline All & 54.0 & 72.2 & 66.7 & 66.6 & 56.8 & 53.1 & 45.5 & 54.0 & 45.1 & 42.2 & 49.6 & 48.1 & 50.9 & 50.3 & 41.8 \\
\hline Office/professional & 42.0 & 43.5 & 56.8 & 42.5 & 41.1 & 34.7 & 43.6 & 41.9 & 33.9 & 29.9 & 42.9 & 32.9 & 39.9 & 51.3 & 28.7 \\
\hline Nonrefrigerated warehouse & 11.0 & 14.3 & 7.9 & & 9.4 & 5.9 & 25.1 & 9.3 & 21.9 & 15.3 & 13.4 & 6.3 & 14.1 & 21.1 & 26.8 \\
\hline Education & 58.2 & 79.7 & 73.8 & 79.1 & 61.3 & 60.4 & 38.5 & 59.0 & 64.8 & -3.0 & 40.4 & 53.8 & 45.0 & 54.1 & 46.9 \\
\hline Retail (excluding mall) & 47.4 & 20.8 & 54.5 & 58.1 & 48.0 & 49.7 & 33.7 & 46.7 & 45.0 & & 46.5 & 47.8 & 47.1 & 50.4 & 42.7 \\
\hline Public assembly & 55.7 & 62.6 & 63.2 & & 40.9 & 64.0 & -40.9 & 48.7 & 56.6 & 63.8 & 48.5 & 63.7 & 69.1 & 65.2 & 38.3 \\
\hline Service & 18.1 & 39.3 & 18.6 & & 20.1 & 10.7 & 23.3 & 22.6 & 12.6 & & 13.7 & 23.5 & 14.7 & 23.6 & 10.0 \\
\hline Religious worship & 49.5 & & 59.6 & & 51.7 & 60.6 & & 45.0 & 66.5 & & 43.7 & 41.2 & 42.5 & 46.7 & \\
\hline Lodging & 60.0 & 76.6 & 69.0 & & 59.5 & 55.9 & & 65.8 & 38.9 & 32.4 & 57.1 & 51.3 & 49.4 & 55.8 & 42.0 \\
\hline Food services & 78.9 & 94.7 & 79.8 & & 78.7 & 78.9 & 86.8 & 81.3 & & 94.4 & 72.7 & 79.6 & 72.6 & 60.8 & 88.3 \\
\hline Health care (inpatient) & 82.9 & 96.9 & 92.4 & 90.5 & 80.1 & 87.6 & 82.1 & 81.9 & 65.0 & & 83.2 & 69.6 & 81.9 & 55.1 & 60.7 \\
\hline Public order and safety & 33.9 & & 52.1 & & 39.8 & 51.8 & & 58.0 & & & 32.9 & -42.8 & 18.7 & 16.8 & \\
\hline Food sales & 51.3 & & 52.7 & & 56.9 & 42.7 & 43.9 & 47.9 & & & 54.3 & 50.5 & 41.4 & & 27.8 \\
\hline Health care (outpatient) & 60.1 & 23.2 & 61.4 & & 45.2 & 62.3 & & 71.2 & 42.7 & & 61.7 & 55.2 & 42.2 & 68.9 & 70.0 \\
\hline Vacant & 32.1 & & 0.0 & 70.8 & 0.0 & 0.0 & 0.0 & 0.0 & 0.0 & 61.1 & 64.9 & 71.8 & 52.2 & & 21.3 \\
\hline Other & 15.2 & & 29.6 & & 10.3 & 6.3 & & 15.0 & 40.6 & & 17.0 & 31.8 & 7.0 & 14.6 & 10.2 \\
\hline Skilled nursing & 62.4 & & 81.1 & & 66.1 & 63.4 & & 50.7 & & & 64.3 & 55.4 & 59.6 & 65.1 & \\
\hline Laboratory & 42.2 & & & & 67.2 & -7.5 & & 52.1 & & & 37.8 & & 87.6 & 54.5 & \\
\hline Refrigerated warehouse & 21.2 & & & & & & & 19.3 & & & 4.1 & 25.2 & 30.1 & & \\
\hline
\end{tabular}


Table 3-19 Existing Stock, No Minimum Mechanical Ventilation, Gas EUI Percent Change for Climate Zone and Subsector

\begin{tabular}{|c|c|c|c|c|c|c|c|c|c|c|c|c|c|c|c|}
\hline \multirow{2}{*}{ Subsector } & \multicolumn{15}{|c|}{ Climate Zone } \\
\hline & All & $1 \mathrm{~A}$ & $2 A$ & 2B & $3 A$ & 3B & $3 C$ & 4A & 4B & 4C & $5 A$ & 5B & $6 A$ & 6B & 7 \\
\hline All & 21.3 & 0.0 & 7.5 & 29.6 & 18.3 & 12.9 & 10.5 & 20.1 & 38.3 & 41.4 & 22.5 & 33.3 & 22.4 & 26.9 & 25.1 \\
\hline Office/professional & 18.6 & 0.0 & 10.7 & 2.3 & 13.5 & 15.4 & 0.7 & 15.1 & 13.4 & 12.5 & 20.4 & 25.2 & 20.8 & 32.2 & 15.1 \\
\hline Nonrefrigerated warehouse & 8.7 & 0.0 & 5.2 & & 7.5 & 5.4 & 7.0 & 6.0 & 22.1 & 7.5 & 8.9 & 7.7 & 7.7 & 6.7 & 21.3 \\
\hline Education & 16.4 & 0.3 & 10.7 & 0.0 & 34.6 & 25.3 & 0.0 & 19.0 & 59.1 & 12.2 & 8.8 & 30.7 & 5.6 & 37.2 & 31.5 \\
\hline Retail (excluding mall) & 27.8 & 0.0 & 30.5 & 35.1 & 36.0 & 29.1 & 7.9 & 29.1 & 20.2 & & 25.7 & 39.0 & 24.4 & 32.6 & 18.8 \\
\hline Public assembly & 27.7 & -1.3 & 32.1 & & 17.1 & 41.5 & 46.3 & 15.7 & 44.8 & 74.8 & 26.9 & 36.4 & 27.9 & 18.7 & 12.5 \\
\hline Service & 9.8 & 0.0 & 4.3 & & 9.7 & 4.6 & 4.7 & 10.2 & 6.7 & & 10.6 & 11.6 & 5.2 & 9.6 & 7.2 \\
\hline Religious worship & 17.3 & & 22.8 & & 22.6 & 27.8 & & 16.0 & 52.6 & & 13.8 & 17.2 & 18.3 & 15.3 & \\
\hline Lodging & 25.3 & 0.0 & -4.8 & & 14.0 & 5.9 & & 27.6 & 41.1 & 0.0 & 31.1 & 42.4 & 22.7 & 43.8 & 16.9 \\
\hline Food services & 16.1 & 0.0 & 3.4 & & 11.7 & 2.6 & 0.3 & 14.1 & & 42.2 & 21.3 & 28.7 & 26.8 & 14.6 & 60.8 \\
\hline Health care (inpatient) & 56.2 & 0.0 & 24.3 & 18.8 & 47.6 & 39.8 & 43.1 & 54.9 & 67.7 & & 62.7 & 65.2 & 71.0 & 57.3 & 76.8 \\
\hline Public order and safety & 25.2 & & -8.7 & & 7.8 & 18.9 & & 19.3 & & & 14.5 & 50.6 & 41.2 & 19.9 & \\
\hline Food sales & 29.8 & & 17.5 & & 29.1 & 8.0 & 4.8 & 22.9 & & & 40.4 & 28.9 & 23.6 & & 10.6 \\
\hline Health care (outpatient) & 26.1 & 0.0 & 10.9 & & 12.5 & 5.3 & & 39.9 & -11.7 & & 27.9 & 49.5 & 18.8 & 34.6 & 50.5 \\
\hline Vacant & 29.9 & & 19.3 & 2.3 & 10.1 & 9.4 & 0.0 & 37.0 & 0.0 & -0.8 & 35.8 & 46.6 & 5.5 & & 3.7 \\
\hline Other & 1.4 & & 5.3 & & 2.7 & 0.0 & & -5.0 & 19.2 & & 4.1 & 10.2 & 1.7 & -0.1 & -3.9 \\
\hline Skilled nursing & 26.9 & & 10.1 & & 0.0 & 3.5 & & 25.9 & & & 35.3 & 41.7 & 14.3 & 62.0 & \\
\hline Laboratory & 0.4 & & & & 0.0 & 3.1 & & 2.1 & & & -0.8 & & 1.8 & 0.2 & \\
\hline Refrigerated warehouse & 9.8 & & & & & & & 6.9 & & & -5.2 & 0.0 & 14.7 & & \\
\hline
\end{tabular}


Table 3-20 Existing Stock, No Minimum Mechanical Ventilation, Electric EUI Percent Change for Climate Zone and Subsector

\begin{tabular}{|c|c|c|c|c|c|c|c|c|c|c|c|c|c|c|c|}
\hline \multirow{2}{*}{ Subsector } & \multicolumn{15}{|c|}{ Climate Zone } \\
\hline & All & $1 \mathrm{~A}$ & $2 A$ & 2B & $3 A$ & 3B & $3 C$ & $4 A$ & 4B & $4 C$ & $5 A$ & $5 B$ & $6 A$ & $6 B$ & 7 \\
\hline All & 0.0 & 5.7 & 3.2 & 0.3 & 0.4 & -1.0 & -3.2 & -0.1 & 0.3 & -1.8 & -0.8 & -0.8 & -1.0 & -0.6 & 0.4 \\
\hline Office/professional & 0.1 & 1.1 & 2.0 & 0.6 & 0.9 & 0.1 & -2.8 & -0.7 & 0.1 & -1.2 & 0.0 & -0.4 & 0.7 & 0.8 & 3.9 \\
\hline Nonrefrigerated warehouse & 0.3 & 1.2 & 0.5 & & 0.2 & 0.0 & -3.0 & 0.1 & 0.0 & 1.6 & 0.3 & 0.3 & 0.8 & 0.0 & 0.0 \\
\hline Education & 1.3 & 7.5 & 4.4 & 0.4 & 2.2 & 0.5 & -2.5 & 0.9 & 3.5 & 0.6 & 0.2 & -0.2 & -0.2 & -1.8 & 6.3 \\
\hline Retail (excluding mall) & 1.2 & 3.0 & 3.0 & 1.7 & 2.0 & 0.0 & -0.8 & 2.1 & 1.0 & & 0.3 & -0.1 & -0.2 & -0.9 & -0.6 \\
\hline Public assembly & 0.4 & 5.7 & 3.3 & & 1.6 & 0.4 & 1.1 & 2.4 & 0.2 & -8.3 & 0.2 & 0.1 & -4.2 & -0.1 & 0.9 \\
\hline Service & 0.1 & 2.9 & 0.9 & & 0.5 & 0.2 & -0.7 & 0.1 & 0.0 & & -0.3 & -0.1 & 0.6 & 0.0 & 0.0 \\
\hline Religious worship & 2.3 & & 5.2 & & 3.7 & 0.7 & & 3.3 & 0.3 & & 1.8 & 1.3 & 0.6 & -0.1 & \\
\hline Lodging & 1.3 & 7.8 & 6.9 & & -0.1 & -1.3 & & 1.0 & -0.2 & 6.7 & 0.1 & -2.3 & 1.2 & -1.9 & -1.8 \\
\hline Food services & -2.5 & 13.5 & 3.1 & & -1.0 & -7.0 & 0.0 & -3.8 & & -1.2 & -4.8 & -4.8 & -8.3 & -3.4 & -5.4 \\
\hline Health care (inpatient) & -4.5 & 7.4 & 4.5 & -1.6 & -2.3 & -7.5 & -22.5 & -2.4 & -10.9 & & -10.8 & -8.7 & -1.7 & -2.5 & -3.5 \\
\hline Public order and safety & 0.7 & & 2.0 & & 1.5 & 0.1 & & 0.2 & & & -0.2 & 3.0 & 0.5 & -0.2 & \\
\hline Food sales & 0.2 & & 2.0 & & -0.3 & -0.3 & -3.4 & 0.8 & & & -0.3 & -0.4 & -0.5 & & 0.0 \\
\hline Health care (outpatient) & 1.1 & 0.7 & 3.9 & & 2.5 & -1.7 & & 1.3 & -0.3 & & 2.1 & -0.8 & 2.0 & -3.1 & -2.9 \\
\hline Vacant & -0.2 & & 2.6 & 3.9 & 0.2 & -4.0 & 0.0 & 1.0 & 8.0 & -0.2 & -0.2 & -0.3 & -0.2 & & -0.4 \\
\hline Other & 0.0 & & 1.0 & & 0.1 & 0.0 & & -0.3 & 0.4 & & 0.0 & 0.1 & 0.2 & -0.1 & 0.1 \\
\hline Skilled nursing & -0.7 & & 3.4 & & 3.5 & -1.0 & & -3.0 & & & -3.2 & 1.3 & -2.1 & -0.2 & \\
\hline Laboratory & -0.2 & & & & -0.6 & 0.9 & & -1.6 & & & 0.3 & & -1.0 & 0.0 & \\
\hline Refrigerated warehouse & 0.3 & & & & & & & 0.5 & & & 0.0 & 0.1 & -0.4 & & \\
\hline
\end{tabular}


Table 3-21 Existing Stock, No Minimum Mechanical Ventilation, Peak Electrical Power Percent Change for Climate Zone and Subsector

\begin{tabular}{|c|c|c|c|c|c|c|c|c|c|c|c|c|c|c|c|}
\hline \multirow{2}{*}{ Subsector } & \multicolumn{15}{|c|}{ Climate Zone } \\
\hline & All & $1 \mathrm{~A}$ & $2 A$ & 2B & 3A & 3B & $3 C$ & 4A & 4B & $4 C$ & 5A & 5B & $6 \mathrm{~A}$ & 6B & 7 \\
\hline All & 5.8 & 5.9 & 7.1 & 5.7 & 7.3 & 4.7 & 2.6 & 6.7 & 5.4 & 8.1 & 4.9 & 4.1 & 5.3 & 2.5 & 2.1 \\
\hline Office/professional & 3.7 & 0.1 & 3.4 & 1.9 & 4.5 & 2.6 & 1.8 & 4.1 & 3.0 & 9.6 & 3.9 & 3.8 & 3.6 & 5.7 & 1.9 \\
\hline Nonrefrigerated warehouse & 0.9 & 0.0 & 1.1 & & 0.5 & 1.0 & 1.5 & 0.9 & 0.0 & 0.3 & 1.2 & 1.1 & 0.6 & 0.2 & 0.1 \\
\hline Education & 7.4 & 18.6 & 8.4 & 8.0 & 12.0 & 8.8 & 5.6 & 7.8 & 11.3 & 5.0 & 3.9 & 3.4 & 4.4 & 2.7 & 5.3 \\
\hline Retail (excluding mall) & 4.4 & 0.0 & 6.8 & 9.6 & 4.2 & 3.8 & 3.3 & 6.2 & 2.2 & & 2.6 & 4.3 & 2.3 & 4.4 & 2.3 \\
\hline Public assembly & 6.8 & 4.2 & 8.7 & & 5.7 & 0.9 & -3.0 & 7.3 & 1.5 & 10.3 & 2.5 & 3.0 & 16.9 & 0.0 & -0.9 \\
\hline Service & 1.1 & 0.1 & 1.3 & & 2.5 & 1.8 & 0.1 & 0.9 & 0.0 & & 1.0 & 1.8 & 0.2 & 0.4 & 0.0 \\
\hline Religious worship & 5.5 & & 9.2 & & 8.8 & 5.0 & & 5.1 & 8.2 & & 3.9 & 0.9 & 1.6 & 1.8 & \\
\hline Lodging & 13.1 & 14.2 & 13.7 & & 10.0 & 9.4 & & 21.1 & 2.9 & 30.5 & 6.3 & 10.6 & 8.7 & 1.9 & 1.4 \\
\hline Food services & 7.8 & 21.5 & 6.8 & & 7.3 & 6.8 & 0.0 & 8.8 & & 6.8 & 8.2 & 3.3 & 8.3 & 0.0 & 7.9 \\
\hline Health care (inpatient) & 14.9 & -0.5 & 26.5 & 24.0 & 9.4 & 15.6 & 11.2 & 10.4 & -0.8 & & 21.2 & 5.6 & 8.7 & 3.3 & -14.4 \\
\hline Public order and safety & 3.8 & & 2.0 & & 6.7 & 3.0 & & 4.0 & & & 3.4 & 6.7 & 3.9 & 1.7 & \\
\hline Food sales & 4.8 & & 5.0 & & 5.6 & 2.1 & 3.3 & 5.2 & & & 6.1 & 2.3 & 2.5 & & 2.8 \\
\hline Health care (outpatient) & 8.1 & 0.1 & 5.6 & & 12.7 & 4.3 & & 9.4 & 0.3 & & 9.7 & 6.4 & 3.5 & 2.6 & 25.4 \\
\hline Vacant & 6.5 & & 8.5 & 3.5 & 4.7 & 5.2 & 0.0 & 11.0 & 29.4 & 8.4 & 8.5 & 0.0 & 2.0 & & 3.7 \\
\hline Other & 1.0 & & 3.3 & & 1.4 & 1.2 & & 1.6 & 3.1 & & 0.3 & 0.0 & 0.2 & 1.3 & 0.0 \\
\hline Skilled nursing & 15.2 & & 18.4 & & 12.9 & 10.4 & & 20.0 & & & 12.1 & 29.1 & 14.0 & 0.4 & \\
\hline Laboratory & 6.7 & & & & 8.9 & 4.2 & & 5.5 & & & 6.5 & & 1.3 & 0.1 & \\
\hline Refrigerated warehouse & 3.1 & & & & & & & 3.3 & & & 0.1 & 1.7 & 4.4 & & \\
\hline
\end{tabular}




\subsection{Max Tech}

The effects of outside air could change significantly for high-performance buildings. To address this possibility, we studied a set of building models based on projected construction in 2025 . These models are the Max Tech Construction Group scenarios described in Section 2.2. For the Max Tech Construction Group, a reference scenario and a scenario with the minimum mechanical ventilation requirement set to zero are simulated. The aggregate results for the entire commercial sector are presented in Table 3-22 through Table 3-26. The results are again shown in absolute terms and as percent and relative changes.

Table 3-22 shows the total site EUIs. The minimum ventilation has a lesser effect on the 90.12004Construction Group than the Existing Stock Construction Group. The trend continues here; the required ventilation has an even lesser effect on the Max Tech Construction Group than it had on the 90.1-2004 Construction Group. The reduced impact of ventilation is attributed to the fact that the Max Tech buildings have the best outside air management through the use of economizer and heat recovery systems in every building. Insight into the commercial sector variation is again shown for total site EUI with the PDF of Figure 3-5.

Table 3-22 Max Tech, Sector-Wide Average Total Site EUI

\begin{tabular}{|l|c|c|c|c|c|}
\hline \multirow{2}{*}{ Scenario } & \multicolumn{2}{|c|}{ Absolute } & \multicolumn{2}{c|}{$\begin{array}{c}\text { Decrease Relative to } \\
\text { Reference }\end{array}$} & $\begin{array}{c}\text { Percent } \\
\text { Decrease } \\
\text { Relative to } \\
\text { Reference }\end{array}$ \\
\cline { 2 - 6 } & $\left(\mathbf{k B t u}^{2} \mathbf{f t}^{2} \cdot \mathbf{y r}\right)$ & $\left(\mathbf{M J} / \mathbf{m}^{\mathbf{2}} \cdot \mathbf{y r}\right)$ & $\left(\mathbf{k B t u} / \mathrm{ft}^{2} \cdot \mathbf{y r}\right)$ & $\left(\mathbf{M J} / \mathbf{m}^{2} \cdot \mathbf{y r}\right)$ & $0.0 \%$ \\
\hline \hline Reference & 38.5 & 437.0 & 0.00 & 0.00 & \\
\hline $\begin{array}{l}\text { No Minimum Mechanical } \\
\text { Ventilation }\end{array}$ & 38.2 & 434.1 & 0.26 & 2.91 & $0.7 \%$ \\
\hline
\end{tabular}




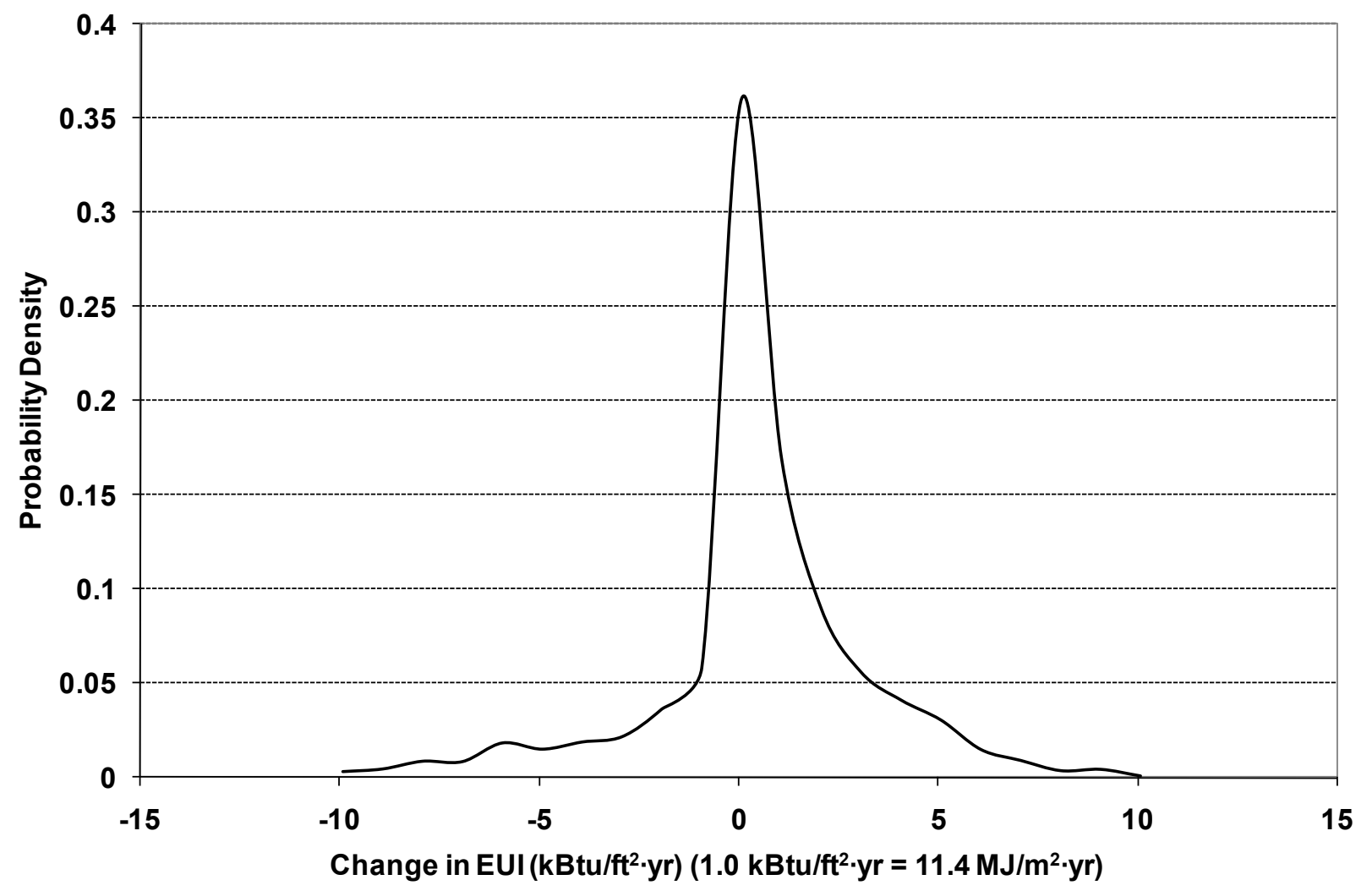

Figure 3-5 PDF of Change in Sector Average EUI for Max Tech, No Minimum Mechanical Ventilation

The diminished impact of minimum ventilation is perhaps more pronounced, considering that required ventilation is a larger fraction of the air change rate compared to the 90.1-2004 and Existing Stock construction groups. Table 3-23 shows that minimum ventilation is $63.6 \%$ of the total outside air rate. The effect on the gas EUI is $8.9 \%$ (see Table 3-24). Table 3-25 shows that the minimum ventilation rate improves the electricity EUI by 8.9\%, which was observed for the 90.1-2004 Construction Group, although to a lesser extent. The electrical energy savings from minimum ventilation suggest missed opportunities for economizing. In terms of electrical power, required ventilation again increases the peak demand (Table 3-26).

Table 3-23 Max Tech, Sector-Wide Average ACH

\begin{tabular}{|l|c|c|c|}
\hline \multicolumn{1}{|c|}{ Scenario } & $\begin{array}{c}\text { Absolute } \\
(\mathbf{1 / h})\end{array}$ & $\begin{array}{c}\text { Decrease Relative } \\
\text { to Reference } \\
(\mathbf{1 / h})\end{array}$ & $\begin{array}{c}\text { Percent Decrease } \\
\text { Relative to } \\
\text { Reference }\end{array}$ \\
\hline Reference & 0.59 & 0.00 & $0.00 \%$ \\
\hline $\begin{array}{l}\text { No Minimum Mechanical } \\
\text { Ventilation }\end{array}$ & 0.22 & 0.38 & $63.58 \%$ \\
\hline
\end{tabular}


Table 3-24 Max Tech, Sector-Wide Average Gas EUI

\begin{tabular}{|c|c|c|c|c|c|}
\hline \multirow{2}{*}{ Scenario } & \multicolumn{2}{|c|}{ Absolute } & \multicolumn{2}{|c|}{$\begin{array}{c}\text { Decrease Relative to } \\
\text { Reference }\end{array}$} & \multirow{2}{*}{$\begin{array}{c}\text { Percent } \\
\text { Decrease } \\
\text { Relative to } \\
\text { Reference }\end{array}$} \\
\hline & $\left(\mathrm{kBtu} / \mathrm{ft}^{2} \cdot \mathrm{yr}\right)$ & $\left(\mathrm{MJ} / \mathrm{m}^{2} \cdot \mathrm{yr}\right)$ & $\left(\mathrm{kBtu} / \mathrm{ft}^{2} \cdot \mathrm{yr}\right)$ & $\left(\mathrm{MJ} / \mathrm{m}^{2} \cdot \mathrm{yr}\right)$ & \\
\hline Reference & 11.9 & 135.4 & 0.00 & 0.00 & $0.0 \%$ \\
\hline $\begin{array}{l}\text { No Minimum Mechanical } \\
\text { Ventilation }\end{array}$ & 10.9 & 123.3 & 1.07 & 12.10 & $8.9 \%$ \\
\hline
\end{tabular}

Table 3-25 Max Tech, Sector-Wide Average Electric EUI

\begin{tabular}{|c|c|c|c|c|c|}
\hline \multirow{2}{*}{ Scenario } & \multicolumn{2}{|c|}{ Absolute } & \multicolumn{2}{|c|}{$\begin{array}{c}\text { Decrease Relative to } \\
\text { Reference }\end{array}$} & \multirow{2}{*}{$\begin{array}{c}\text { Percent } \\
\text { Decrease } \\
\text { Relative tc } \\
\text { Reference }\end{array}$} \\
\hline & $\left(\mathrm{kBtu} / \mathrm{ft}^{2} \cdot \mathrm{yr}\right)$ & $\left(\mathrm{MJ} / \mathrm{m}^{2} \cdot \mathrm{yr}\right)$ & $\left(\mathrm{kBtu} / \mathrm{ft}^{2} \cdot \mathrm{yr}\right)$ & $\left(\mathrm{MJ} / \mathrm{m}^{2} \cdot \mathrm{yr}\right)$ & \\
\hline Reference & 26.3 & 298.6 & 0.00 & 0.00 & $0.0 \%$ \\
\hline $\begin{array}{l}\text { No Minimum Mechanical } \\
\text { Ventilation }\end{array}$ & 27.1 & 307.7 & -0.81 & -9.19 & $-3.1 \%$ \\
\hline
\end{tabular}

Table 3-26 Max Tech, Sector-Wide Average Peak Electrical Power

\begin{tabular}{|c|c|c|c|c|c|}
\hline \multirow{2}{*}{ Scenario } & \multicolumn{2}{|c|}{ Absolute } & \multicolumn{2}{|c|}{$\begin{array}{c}\text { Decrease Relative to } \\
\text { Reference }\end{array}$} & \multirow{2}{*}{$\begin{array}{c}\text { Percent } \\
\text { Decrease } \\
\text { Relative to } \\
\text { Reference }\end{array}$} \\
\hline & $\left(\mathrm{kBtu} / \mathrm{ft}^{2} \cdot \mathrm{yr}\right)$ & $\left(\mathrm{MJ} / \mathrm{m}^{2} \cdot \mathrm{yr}\right)$ & $\left(k B t u / f^{2} \cdot y r\right)$ & $\left(\mathrm{MJ} / \mathrm{m}^{2} \cdot \mathrm{yr}\right)$ & \\
\hline Reference & 2.45 & 26.39 & 0.00 & 0.00 & $0.00 \%$ \\
\hline $\begin{array}{l}\text { No Minimum Mechanical } \\
\text { Ventilation }\end{array}$ & 2.40 & 25.78 & 0.06 & 0.61 & $2.32 \%$ \\
\hline
\end{tabular}

We used the format established for the 90.1-2004 and Existing Stock construction group models to present the climatic and programmatic influences in Table 3-27 through Table 3-31 and to observe similar trends. 
Table 3-27 Max Tech, No Minimum Mechanical Ventilation, Total EUI Percent Change for Climate Zone and Subsector

\begin{tabular}{|c|c|c|c|c|c|c|c|c|c|c|c|c|c|c|c|}
\hline \multirow{2}{*}{ Subsector } & \multicolumn{15}{|c|}{ Climate Zone } \\
\hline & All & $1 \mathrm{~A}$ & 2A & 2B & $3 A$ & 3B & $3 C$ & 4A & 4B & $4 C$ & $5 \mathrm{~A}$ & $5 B$ & $6 \mathrm{~A}$ & 6B & 7 \\
\hline All & 0.7 & 0.3 & -3.4 & -2.6 & 0.9 & -1.1 & 0.3 & 1.1 & 2.6 & 2.5 & 1.4 & 2.4 & 2.2 & 5.4 & 2.5 \\
\hline Office/professional & -0.1 & 1.8 & -1.7 & -0.7 & 0.3 & -0.5 & -0.8 & -0.2 & 0.0 & 0.9 & 0.0 & 0.5 & 0.7 & 1.5 & 2.2 \\
\hline Nonrefrigerated warehouse & 3.3 & 1.6 & -4.0 & & 3.9 & 3.7 & -3.1 & 7.1 & 9.8 & 12.4 & 2.9 & 6.2 & 3.8 & 8.7 & 0.1 \\
\hline Education & -0.3 & -19.2 & -11.2 & -2.9 & -4.2 & -7.0 & 2.1 & 2.1 & -1.7 & 14.6 & 5.2 & 8.4 & 0.6 & 13.0 & 23.1 \\
\hline Retail (excluding mall) & 2.2 & 3.4 & -6.7 & 3.4 & 0.8 & -5.0 & 3.9 & 3.6 & -3.0 & & 7.8 & 2.2 & 7.8 & 0.8 & 10.3 \\
\hline Public assembly & -0.4 & -0.8 & -3.3 & & -3.9 & -1.2 & -0.5 & 0.3 & 1.8 & -1.6 & 3.7 & -0.8 & -1.1 & -1.0 & -0.1 \\
\hline Service & 6.2 & -8.3 & -11.4 & & 5.8 & -1.6 & -2.6 & 7.5 & 9.0 & & 5.9 & 11.2 & 11.5 & 12.5 & 15.3 \\
\hline Religious worship & 5.0 & & -15.4 & & 3.2 & 1.6 & & 10.2 & 13.0 & & 6.6 & 8.2 & 7.9 & 11.3 & \\
\hline Lodging & 0.0 & 0.0 & 0.0 & & 0.0 & 0.0 & & 0.0 & 0.0 & 0.0 & 0.0 & 0.0 & 0.0 & 0.0 & 0.0 \\
\hline Food services & -0.6 & 1.4 & -0.5 & & -0.5 & 0.0 & -0.1 & -0.9 & & -0.2 & -0.4 & -1.8 & -0.4 & -2.4 & -10.3 \\
\hline Health care (inpatient) & 4.7 & 2.0 & 5.5 & 0.1 & 14.6 & 1.6 & 0.4 & 3.3 & 3.9 & & -1.3 & 0.9 & 5.2 & 6.9 & -3.8 \\
\hline Public order and safety & -0.1 & & 0.9 & & -0.3 & 0.0 & & -0.8 & & & 0.3 & -0.8 & 0.7 & -2.7 & \\
\hline Food sales & -1.3 & & -1.2 & & -2.5 & -1.6 & -2.6 & -2.2 & & & -1.1 & -0.8 & 1.5 & & -1.5 \\
\hline Health care (outpatient) & -1.8 & 6.1 & -15.4 & & -11.1 & -16.1 & & -0.1 & 5.2 & & -0.1 & 8.0 & 12.0 & 7.7 & 19.0 \\
\hline Vacant & 0.7 & & 0.0 & 1.4 & 0.8 & 0.0 & 0.0 & 0.0 & 0.0 & 1.1 & 0.1 & 2.2 & -0.9 & & 7.2 \\
\hline Other & -0.8 & & -2.8 & & -2.6 & 0.7 & & -1.4 & 6.9 & & 4.5 & 3.6 & -6.0 & 6.7 & -2.7 \\
\hline Skilled nursing & -4.3 & & -6.6 & & -16.4 & 2.8 & & -9.3 & & & -1.0 & -8.0 & 1.7 & 9.4 & \\
\hline Laboratory & -0.4 & & & & 0.1 & -0.1 & & 0.2 & & & -1.1 & & -0.4 & 0.5 & \\
\hline Refrigerated warehouse & 1.4 & & & & & & & 0.4 & & & 1.9 & 0.9 & 3.3 & & \\
\hline
\end{tabular}


Table 3-28 Max Tech, No Minimum Mechanical Ventilation, ACH Percent Change for Climate Zone and Subsector

\begin{tabular}{|c|c|c|c|c|c|c|c|c|c|c|c|c|c|c|c|}
\hline \multirow{2}{*}{ Subsector } & \multicolumn{15}{|c|}{ Climate Zone } \\
\hline & All & $1 \mathrm{~A}$ & $2 A$ & 2B & 3A & 3B & $3 C$ & 4A & 4B & 4C & 5A & $5 B$ & $6 A$ & 6B & 7 \\
\hline All & 63.6 & 80.7 & 72.0 & 57.0 & 64.4 & 62.0 & 38.3 & 60.6 & 69.5 & 48.3 & 63.5 & 60.1 & 66.9 & 65.3 & 58.8 \\
\hline Office/professional & 50.6 & 77.8 & 60.4 & 49.6 & 53.0 & 49.8 & 31.0 & 47.7 & 36.4 & 35.3 & 52.8 & 42.2 & 58.2 & 55.4 & 54.4 \\
\hline Nonrefrigerated warehouse & 60.9 & 69.1 & 58.1 & & 61.1 & 60.3 & 35.2 & 61.7 & 49.1 & 70.6 & 60.3 & 60.1 & 64.6 & 66.0 & 61.6 \\
\hline Education & 80.7 & 89.5 & 86.8 & 79.6 & 79.6 & 81.6 & 66.0 & 78.4 & 84.9 & 80.7 & 80.0 & 77.3 & 80.5 & 75.3 & 84.9 \\
\hline Retail (excluding mall) & 76.4 & 84.5 & 76.2 & 65.6 & 76.0 & 72.6 & 71.2 & 76.4 & 72.8 & & 78.0 & 68.6 & 80.6 & 72.5 & 81.7 \\
\hline Public assembly & 63.0 & 71.5 & 72.8 & & 59.9 & 60.2 & 48.0 & 61.0 & 67.1 & 41.6 & 66.2 & 53.0 & 66.4 & 45.4 & 65.3 \\
\hline Service & 80.1 & 84.6 & 81.0 & & 82.9 & 80.9 & 78.1 & 78.9 & 81.3 & & 79.0 & 76.0 & 83.5 & 80.3 & 81.8 \\
\hline Religious worship & 77.4 & & 74.4 & & 79.5 & 75.0 & & 77.6 & 79.5 & & 78.3 & 76.1 & 78.0 & 76.6 & \\
\hline Lodging & 0.0 & 0.0 & 0.0 & & 0.0 & 0.0 & & 0.0 & 0.0 & 0.0 & 0.0 & 0.0 & 0.0 & 0.0 & 0.0 \\
\hline Food services & 43.1 & 93.6 & 57.7 & & 43.9 & 45.2 & 23.5 & 38.4 & & 28.7 & 41.1 & 24.0 & 41.0 & 32.1 & 40.5 \\
\hline Health care (inpatient) & 66.6 & 97.0 & 78.9 & 48.4 & 71.9 & 58.0 & 48.2 & 66.7 & 63.3 & & 63.9 & 51.0 & 70.4 & 62.6 & 56.1 \\
\hline Public order and safety & 47.3 & & 63.2 & & 54.0 & 46.8 & & 44.5 & & & 46.8 & 35.1 & 49.8 & 27.9 & \\
\hline Food sales & 55.9 & & 57.6 & & 54.5 & 54.3 & 49.5 & 54.5 & & & 59.3 & 42.9 & 62.4 & & 47.8 \\
\hline Health care (outpatient) & 81.0 & 92.5 & 84.6 & & 83.2 & 74.1 & & 78.5 & 81.1 & & 80.5 & 80.4 & 85.4 & 79.9 & 83.8 \\
\hline Vacant & 65.9 & & 0.0 & 57.9 & 76.0 & 84.0 & 0.0 & 49.0 & 0.0 & 37.1 & 56.2 & 68.5 & 72.1 & & 63.7 \\
\hline Other & 57.5 & & 57.0 & & 52.0 & 48.0 & & 54.0 & 70.7 & & 58.8 & 57.3 & 62.2 & 66.4 & 63.9 \\
\hline Skilled nursing & 71.0 & & 79.8 & & 73.2 & 65.2 & & 69.8 & & & 70.9 & 58.9 & 72.8 & 68.9 & \\
\hline Laboratory & 29.8 & & & & 29.7 & 32.0 & & 28.2 & & & 30.9 & & 33.4 & 18.5 & \\
\hline Refrigerated warehouse & 57.5 & & & & & & & 57.5 & & & 63.6 & 56.5 & 58.3 & & \\
\hline
\end{tabular}


Table 3-29

Max Tech, No Minimum Mechanical Ventilation, Gas EUI Percent Change for Climate Zone and Subsector

\begin{tabular}{|c|c|c|c|c|c|c|c|c|c|c|c|c|c|c|c|}
\hline \multirow{2}{*}{ Subsector } & \multicolumn{15}{|c|}{ Climate Zone } \\
\hline & All & $1 \mathrm{~A}$ & $2 A$ & 2B & 3A & 3B & $3 C$ & 4A & 4B & $4 C$ & $5 A$ & $5 B$ & $6 \mathrm{~A}$ & $6 B$ & 7 \\
\hline All & 8.9 & 0.6 & 1.6 & 0.6 & 9.0 & 5.1 & 3.9 & 11.3 & 19.6 & 15.5 & 8.5 & 15.0 & 9.8 & 18.1 & 14.0 \\
\hline Office/professional & 7.1 & -2.7 & 0.3 & -0.4 & 10.4 & 3.3 & 1.2 & 7.7 & 1.2 & 13.1 & 5.7 & 13.9 & 8.3 & 13.2 & 17.8 \\
\hline Nonrefrigerated warehouse & 11.3 & 1.0 & 5.0 & & 14.0 & 22.8 & 0.0 & 18.3 & 24.5 & 44.2 & 7.2 & 18.6 & 8.4 & 13.7 & 3.6 \\
\hline Education & 18.3 & 1.0 & 3.0 & 29.6 & 12.0 & 15.9 & 24.5 & 22.4 & 60.4 & 46.6 & 17.9 & 35.8 & 9.2 & 33.0 & 66.8 \\
\hline Retail (excluding mall) & 25.8 & -4.2 & 1.9 & -3.7 & 26.3 & 11.5 & 39.8 & 37.7 & 25.5 & & 26.6 & 17.2 & 26.7 & 9.0 & 29.8 \\
\hline Public assembly & 10.0 & 0.0 & 5.4 & & -4.5 & 6.8 & 20.4 & 10.3 & 10.4 & 21.8 & 15.4 & 20.4 & 12.8 & 0.5 & 1.7 \\
\hline Service & 25.7 & 0.2 & 7.6 & & 31.7 & 21.9 & 13.9 & 31.5 & 32.9 & & 20.3 & 33.8 & 22.7 & 37.3 & 34.1 \\
\hline Religious worship & 21.0 & & 10.5 & & 31.4 & 29.8 & & 31.2 & 55.9 & & 16.0 & 23.0 & 15.9 & 17.1 & \\
\hline Lodging & 0.0 & 0.0 & 0.0 & & 0.0 & 0.0 & & 0.0 & 0.0 & 0.0 & 0.0 & 0.0 & 0.0 & 0.0 & 0.0 \\
\hline Food services & 0.0 & 0.0 & 0.0 & & 0.0 & 0.0 & 0.0 & -0.4 & & 0.1 & -0.1 & 0.0 & 0.4 & 0.0 & 0.0 \\
\hline Health care (inpatient) & 18.4 & 0.0 & 10.0 & 1.6 & 32.2 & 9.4 & 8.0 & 17.9 & 18.8 & & 10.2 & 12.7 & 26.9 & 25.9 & 0.2 \\
\hline Public order and safety & 4.3 & & -2.0 & & 6.9 & 1.5 & & 0.7 & & & 9.4 & 1.3 & 6.5 & -0.2 & \\
\hline Food sales & 6.1 & & 1.9 & & 2.7 & 2.9 & 4.7 & 4.8 & & & 6.6 & 7.4 & 12.2 & & 8.2 \\
\hline Health care (outpatient) & 20.4 & 15.6 & 2.0 & & 9.9 & 16.4 & & 23.3 & 15.8 & & 15.7 & 25.4 & 29.9 & 30.2 & 55.5 \\
\hline Vacant & 2.2 & & 0.0 & 1.6 & 2.0 & 0.8 & 0.0 & 0.3 & 0.0 & 0.0 & 0.6 & 15.7 & -0.7 & & 31.1 \\
\hline Other & 1.1 & & 7.4 & & 6.5 & 6.0 & & -2.4 & 17.1 & & 12.0 & 12.3 & -11.3 & 30.5 & -3.8 \\
\hline Skilled nursing & 19.8 & & 2.5 & & 1.4 & 17.6 & & 21.0 & & & 24.2 & 16.0 & 23.1 & 36.3 & \\
\hline Laboratory & -0.5 & & & & 0.0 & -0.2 & & 0.4 & & & -1.3 & & 0.0 & 1.0 & \\
\hline Refrigerated warehouse & 17.5 & & & & & & & 15.4 & & & 15.3 & 8.1 & 24.9 & & \\
\hline
\end{tabular}


Table 3 -30 Max Tech, No Minimum Mechanical Ventilation, Electric EUI Percent Change for Climate Zone and Subsector

\begin{tabular}{|c|c|c|c|c|c|c|c|c|c|c|c|c|c|c|c|}
\hline \multirow{2}{*}{ Subsector } & \multicolumn{15}{|c|}{ Climate Zone } \\
\hline & All & $1 \mathrm{~A}$ & $2 A$ & $2 B$ & $3 A$ & 3B & $3 C$ & $4 \mathrm{~A}$ & $4 B$ & $4 C$ & $5 \mathrm{~A}$ & $5 B$ & $6 A$ & $6 B$ & 7 \\
\hline All & -3.1 & 0.2 & -4.8 & -3.1 & -2.8 & -3.5 & -1.6 & -2.9 & -2.5 & -1.5 & -2.7 & -2.8 & -2.9 & -2.2 & -3.6 \\
\hline Nonrefrigerated warehouse & -2.0 & 1.7 & -5.7 & & -1.7 & -0.3 & -3.1 & -0.9 & -0.6 & 0.3 & -1.8 & -0.6 & -1.6 & -0.1 & -3.3 \\
\hline Education & -8.1 & -19.4 & -13.9 & -5.5 & -8.5 & -11.5 & -3.7 & -6.0 & -13.2 & -5.9 & -3.2 & -4.9 & -6.7 & -6.9 & -3.7 \\
\hline Service & -3.8 & -9.1 & -13.8 & & -3.5 & -8.7 & -8.7 & -2.7 & -0.2 & & -3.2 & -1.1 & -1.5 & -0.7 & -0.9 \\
\hline Religious worship & -5.0 & & -17.0 & & -5.2 & -4.1 & & -2.2 & -1.0 & & -3.1 & -0.7 & -2.0 & -0.1 & \\
\hline Lodging & 0.0 & 0.0 & 0.0 & & 0.0 & 0.0 & & 0.0 & 0.0 & 0.0 & 0.0 & 0.0 & 0.0 & 0.0 & 0.0 \\
\hline Food services & -1.3 & 3.1 & -1.0 & & -1.1 & 0.0 & -0.2 & -1.5 & & -0.9 & -0.8 & -3.7 & -1.4 & -6.0 & -16.1 \\
\hline Health care (outpatient) & -11.4 & 4.1 & -17.5 & & -17.0 & -26.6 & & -10.1 & -0.2 & & -9.7 & -0.2 & -1.5 & -5.7 & -6.0 \\
\hline Vacant & -0.3 & & 0.0 & 1.3 & 0.0 & -0.1 & 0.0 & -0.1 & 0.0 & 1.2 & -0.2 & -0.1 & -1.0 & & -0.8 \\
\hline Other & -1.5 & & -4.5 & & -3.5 & 0.2 & & -1.0 & 0.6 & & -0.1 & -0.3 & -3.4 & -0.2 & -2.4 \\
\hline Skilled nursing & -13.9 & & -8.6 & & -20.1 & -3.3 & & -21.6 & & & -14.3 & -15.7 & -8.5 & -2.7 & \\
\hline Laboratory & -0.3 & & & & 0.1 & 0.0 & & 0.1 & & & -0.9 & & -0.7 & -0.2 & \\
\hline Refrigerated warehouse & -0.9 & & & & & & & -1.3 & & & -0.4 & 0.1 & -1.6 & & \\
\hline
\end{tabular}


Table 3-31 Max Tech, No Minimum Mechanical Ventilation, Peak Electrical Power Percent Change for Climate Zone and Subsector

\begin{tabular}{|c|c|c|c|c|c|c|c|c|c|c|c|c|c|c|c|}
\hline \multirow{2}{*}{ Subsector } & \multicolumn{15}{|c|}{ Climate Zone } \\
\hline & All & $1 \mathrm{~A}$ & $2 A$ & 2B & 3A & 3B & $3 C$ & 4A & 4B & 4C & 5A & 5B & $6 A$ & $6 B$ & 7 \\
\hline All & 2.3 & 2.7 & 1.2 & -0.8 & 2.8 & 1.3 & 0.7 & 2.2 & 3.1 & 3.3 & 2.5 & 3.3 & 4.1 & 2.5 & 3.0 \\
\hline Office/professional & 1.1 & 2.6 & 0.6 & 0.0 & 1.5 & 0.8 & -0.3 & 1.2 & 1.4 & 0.2 & 1.4 & 0.8 & 1.1 & 0.6 & 1.5 \\
\hline Nonrefrigerated warehouse & 3.4 & 0.7 & 3.5 & & 0.5 & 3.5 & 23.9 & 3.9 & 2.2 & 2.1 & 2.9 & 5.6 & 5.4 & 1.9 & 2.9 \\
\hline Education & 4.4 & 1.2 & 2.1 & 2.3 & 7.0 & 0.8 & -1.3 & 4.3 & 5.2 & 14.6 & 4.6 & 7.3 & 5.6 & 2.4 & 16.6 \\
\hline Retail (excluding mall) & 3.1 & 1.1 & 0.7 & 4.5 & 1.2 & 4.4 & 3.2 & 3.1 & 2.2 & & 4.5 & 2.5 & 7.9 & 0.4 & -1.4 \\
\hline Public assembly & 1.5 & -0.1 & -0.8 & & 1.2 & 0.9 & 1.2 & 0.8 & 1.6 & 2.4 & 2.7 & -1.2 & 4.0 & -3.6 & 3.5 \\
\hline Service & 4.7 & -0.1 & -2.5 & & 4.9 & 1.8 & 5.1 & 4.2 & 5.6 & & 5.4 & 7.4 & 9.2 & 7.7 & 8.3 \\
\hline Religious worship & 3.2 & & -1.6 & & 2.8 & 0.5 & & 4.3 & 3.7 & & 5.1 & 8.4 & 5.7 & 1.4 & \\
\hline Lodging & 0.0 & 0.0 & 0.0 & & 0.0 & 0.0 & & 0.0 & 0.0 & 0.0 & 0.0 & 0.0 & 0.0 & 0.0 & 0.0 \\
\hline Food services & 1.2 & 3.9 & 1.2 & & 1.8 & 1.3 & 0.2 & 0.8 & & 1.5 & 1.6 & 0.1 & 1.4 & 0.1 & 0.9 \\
\hline Health care (inpatient) & 5.5 & 5.9 & 11.4 & 5.4 & 4.0 & 3.9 & 0.3 & 7.8 & 4.4 & & 4.1 & -0.4 & 8.0 & 1.7 & 4.2 \\
\hline Public order and safety & 1.1 & & 0.8 & & 1.6 & 2.0 & & 0.9 & & & 2.3 & -1.2 & 1.2 & 1.0 & \\
\hline Food sales & -0.5 & & 0.6 & & -1.2 & 0.0 & 0.2 & -1.2 & & & -1.1 & 0.2 & 2.1 & & -0.4 \\
\hline Health care (outpatient) & 0.9 & 10.0 & -6.8 & & -5.0 & -12.4 & & 3.4 & 8.2 & & 2.2 & 8.9 & 9.0 & 5.6 & 8.9 \\
\hline Vacant & 0.7 & & 0.0 & 2.2 & 2.2 & 0.5 & 0.0 & -0.9 & 0.0 & -1.2 & 0.0 & 0.3 & 1.8 & & 4.3 \\
\hline Other & 1.4 & & 1.0 & & 5.6 & 3.2 & & 0.7 & 2.0 & & 2.3 & 0.4 & 1.0 & 0.6 & 0.5 \\
\hline Skilled nursing & 0.6 & & 5.5 & & -1.6 & 4.9 & & -3.3 & & & -1.2 & -4.1 & 6.2 & 0.9 & \\
\hline Laboratory & 1.9 & & & & 3.0 & 1.1 & & 1.8 & & & 1.5 & & 1.7 & 0.7 & \\
\hline Refrigerated warehouse & 2.5 & & & & & & & 1.7 & & & 3.4 & 2.3 & 3.0 & & \\
\hline
\end{tabular}




\section{Summary and Recommendations}

This research suggests that outside air has a significant impact on the energy consumption of commercial buildings. Depending on the level of construction quality, providing the minimum level of mechanical ventilation for indoor air quality increases the total energy consumption of the commercial buildings sector by $0.7 \%$ to $6.6 \%$. Outside air due to infiltration increases the energy consumption of the sector 9.7\% for construction based on 90.1-2004. On average, mechanical ventilation increases gas energy use, which is typically associated with heating, but actually reduces electrical energy consumption that is usually related to cooling. For example, for the 90.1-2004 gas energy consumption due to minimum mechanical ventilation increases by $20.3 \%$, but reduces electrical energy consumption by $2.8 \%$. These results do not apply to every building or to all climates. In some buildings for example, ventilation reduces the overall energy consumption, because the benefits of economizing overcome any increase in heating energy. In this section we will further analyze our findings related to outside air, specifically in relation to mechanical ventilation and infiltration. We will also discuss the effects of mechanical equipment, including economizers and energy recovery devices. We make recommendations for each item about future actions that have the highest potential to reduce the energy impact of outside air.

Ventilation has a significant effect on all vintages of construction. The effect decreases as the commercial building stock is reconstructed to comply with 90.1-2004, and it decreases even more if buildings are reconstructed using Max Tech. The diminished effect of outside air on newer buildings is primarily attributed to the fact that economizers and energy recovery devices are more commonly installed in new buildings.

The Max Tech Construction Group of this study applied economizers and energy recovery systems to every building in the commercial stock. Ventilation had a minimal impact on the overall energy consumption. From the aggregate sum, there seems to be little opportunity to improve the outside air management of advanced buildings, but the gas and electricity breakdowns lead us to a different conclusion. Ventilation increases the gas EUI for the Max Tech Construction Group by $8.9 \%$ and decreases the electricity EUI by 3.1\%. The two outcomes somewhat offset each other, but individually they indicate room for improvement.

Increases in gas energy, conventionally associated with heating more than cooling, suggest that further research into heat recovery systems would be beneficial. Despite the aggregate results, energy recovery could also more effectively reduce cooling energy in some situations. Current and future studies of advanced heat transfer techniques might be applied to energy recovery devices to more effectively salvage energy from exhaust air. One feature that would increase the benefit of current generation energy recovery devices is a bypass that would reduce fan energy when the energy recovery device is not used. The simulations in this work did not model a bypass as it affects fan energy. Controls in the simulations did, however, disengage the thermodynamic effects of the energy recovery systems during economizing. In future work, advanced controls could be implemented to take into account the fan energy increase and enter bypass mode when the system cannot recover more energy than is consumed by the fan. In relation to energy recovery, this study took a rather brute force approach by applying energy recovery devices to all buildings in the Max Tech Construction Group. Applying these systems to all buildings is probably impractical for real buildings. Further studies that concentrate on energy recovery systems rather than outside air as a whole would help to isolate the best opportunities for energy recovery devices.

The electrical energy savings that are provided by ventilation, even in buildings that have economizers, indicate that the economizers are not optimally controlled. Ideally, simulations would have perfect economizer control; therefore, buildings equipped with economizers would achieve no savings in cooling energy as a result of ventilation. In this study there are savings related to ventilation, even in buildings with economizers. We conclude that the control logic implemented in the simulations was less than optimal, and there are missed opportunities for economizing in the simulations. Future work could refine 
the control logic in the simulations, but even with ideal models, less then optimal control is almost certain in the physical implementations of economizers in real buildings. We recommend further research into the economizer control logic as it is modeled in software and physically implemented.

Infiltration was given less emphasis, but it has a noticeable impact on the energy consumption of the 90.12004 Construction Group (the only type of construction where it was analyzed). Perhaps not surprisingly, based on the average results form this study, a quantity of outside air due to infiltration was found to have a more significant impact on energy consumption than the same volume of air introduced by the mechanical ventilation system. The difference is attributed to the fact that mechanical ventilation systems can properly control and condition outside air while outside air from infiltration is introduced directly to the building. These results are relevant, but there are significant simplifications in the constant volume method used to model infiltration. A more thorough investigation of the effects of infiltration could be conducted by using a more detailed model that more thoroughly accounts for the physics governing air flow. EnergyPlus includes detailed air flow models; however, implementing this type of model on a national scale study would introduce significant challenges because of the many unique buildings.

We tried to break the aggregate results down by climate zone and building type. For instance, the minimum mechanical ventilation increases the total energy consumption of the sector average by $5.4 \%$ to $11.7 \%$ in climate zone $6 \mathrm{~B}$, but decreases the average by $2.6 \%$ to $0.6 \%$ in climate zone $2 \mathrm{~B}$. Colder climates are generally more affected by ventilation. The results are also broken down by building type, but unfortunately the limited number of buildings provided by the CBECS data set in some categories severely degrades the quality of the results. A study based on a larger sample of buildings is one way to improve the accuracy of the detailed results. An alternative, and perhaps more efficient, approach to improving the detailed results is to conduct a study based on a prototypical set of benchmark buildings for each climate zone and subsector. A much smaller number of models would be needed if a set of carefully crafted prototypical buildings were used. A study based on prototypical buildings would be less time consuming, and fewer models would make it feasible to give each model individual attention.

It is not within the scope of this report to recommend changes to the minimum ventilation requirements for commercial buildings, but current technology offers alternative methods of providing healthy indoor air. Advanced filters and ultraviolet light might help meet indoor air quality objectives with reduced ventilation. These options also have parasitic energy loss, and further research is necessary to objectively compare their energy use to conventional ventilation.

Finally, although much of this work focuses on a rather optimistic outlook where all buildings are tightly constructed and have energy recovery and properly controlled economizers, the real world is obviously far from realizing this picture. Indeed, many of our suggestions focus on improving on a scenario that is already far removed from the real world. Based on the results and on personal experience, we believe that the effects of outdoor air can be minimized by ensuring that the targets that we already have are achieved. More effective governance and validation are more important to achieving this goal than are new technical achievements. 


\section{References}

ASHRAE. (2004). ANSI/ASHRAE Standard 62.1-2004: Ventilation for Acceptable Indoor Air Quality. Atlanta, GA: ASHRAE.

ASHRAE. (2004). ANSI/ASHRAE/IESNA Standard 90.1-2004: Energy Standard for Buildings except Low-Rise Residential Buildings. Atlanta, GA: ASHRAE.

Chan, W.R. (2006). Assessing the Effectiveness of Shelter-in-Place as an Emergency Response to LargeScale Outdoor Chemical Releases. Dissertation. Department of Civil and Environmental Engineering, University of California, Berkeley. LBNL-60184.

Colliver, D.G. (1995). Energy Requirements for Conditioning of Ventilating Air. AIVC Technical Note 47. University of Warwick Science Park. Great Britain.

Energy Information Administration. (2006). Annual Energy Outlook 2006. Washington, DC: EIA. Available from http://www.eia.doe.gov/oiaf/aeo.

EIA. (2006a). Annual Energy Review 2006. Washington, DC: EIA. Available from www.eia.doe.gov/emeu/aer/consump.html.

EIA. (2006b). 2003 Commercial Buildings Energy Consumption Survey. Washington, DC: EIA. Available from www.eia.doe.gove/emeu/cbecs/cbecs2003/introduction.html.

Eto, M.; Meyer, C. (1988). "The HVAC Costs of Fresh Air Ventilation.” ASHRAE Transactions 94(2):331-45. Atlanta, GA: ASHRAE.

Emmerich, S.J.; McDowell, T.; Wagdy A. (2005). Investigation of the Impact of Commercial Building Envelope Airtightness on HVAC Energy Use. NISTIR 7238. National Institute of Standards and Technology.

Fisk, W.J. (2000). Health and Productivity Gains from Better Indoor Environments and Their Implications for the U.S. Department of Energy. LBNL-47458. Berkeley, CA: Lawrence Berkeley National Laboratory.

Griffith, B.; Long, N.; Torcellini, P.; Judkoff, R.; Crawley, D.; Ryan, J. (2007). Assessment of the Technical Potential for Achieving Net-Zero-Energy Buildings in the Commercial Sector. NREL/ TP-55041957. Golden, CO: National Renewable Energy Laboratory.

Griffith, B.; Long; N.; Torcellini; P.; Judkoff; R.; Crawley; D.; Ryan, J. (2008). Methodology for Modeling Building Energy Performance across the Commercial Sector. NREL Report No. TP-55041956. Golden, CO: NREL.

Harrje, D.T.; Duil, G.S.; Bohac, D.L.; Gadsby, K.J. (1985). "Documenting Air Movements and Infiltration in Multicell Buildings Using Various Tracer-Gas Techniques." ASHRAE Transactions 91(2B):2012-27. Atlanta, GA: ASHRAE.

Orme, M. (2001). "Estimates of the Energy Impact of Ventilation and Associated Financial Expenditures." Energy and Buildings 33:199-205. Amsterdam: Elsevier Science.

Persily, A.K. (1998) "Airtightness of Commercial and Institutional Buildings: Blowing Holes in the Myth of Tight Buildings." DOE, ASHRAE, ORNL Conference - Thermal Envelopes VII, Clearwater, FL.

Turk, B.H.; Grimsrud, D.T.; Brown, J.T.; Geisling-Sobotka, K.L.; Harrison, J.; Prill, R.J. (1989). "Commercial Building Ventilation Rates and Particle Concentrations." ASHRAE Transactions 95(1):422433. Atlanta, GA: ASHRAE. 


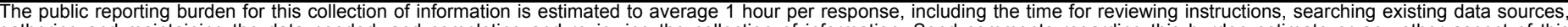

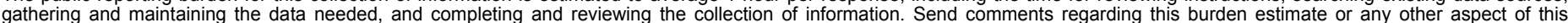

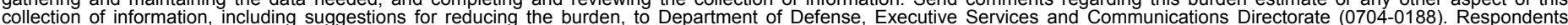

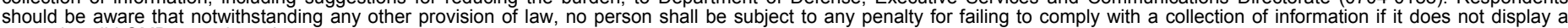

should be aware that notwithstanding

PLEASE DO NOT RETURN YOUR FORM TO THE ABOVE ORGANIZATION.

\begin{tabular}{l|l|l|l} 
1. REPORT DATE (DD-MM-YYYY) & 2. REPORT TYPE & 3. DATES COVERED (FrOm - TO)
\end{tabular} April 2009

Technical Report

4. TITLE AND SUBTITLE

Assessment of the Energy Impacts of Outside Air in the Commercial Sector

5a. CONTRACT NUMBER

DE-AC36-08-GO28308

5b. GRANT NUMBER

5c. PROGRAM ELEMENT NUMBER

6. AUTHOR(S)

K. Benne, B. Griffith, N. Long, P. Torcellini, D. Crawley, and

T. Logee

5d. PROJECT NUMBER

NREL/TP-550-41955

5e. TASK NUMBER

BEC7.1006

5f. WORK UNIT NUMBER
7. PERFORMING ORGANIZATION NAME(S) AND ADDRESS(ES)

National Renewable Energy Laboratory

1617 Cole Blvd.

Golden, CO 80401-3393
8. PERFORMING ORGANIZATION REPORT NUMBER

NREL/TP-550-41955

9. SPONSORING/MONITORING AGENCY NAME(S) AND ADDRESS(ES)

10. SPONSOR/MONITOR'S ACRONYM(S) NREL

11. SPONSORING/MONITORING AGENCY REPORT NUMBER

12. DISTRIBUTION AVAILABILITY STATEMENT

National Technical Information Service

U.S. Department of Commerce

5285 Port Royal Road

Springfield, VA 22161

13. SUPPLEMENTARY NOTES

14. ABSTRACT (Maximum 200 Words)

The enormous quantity of energy consumed by U.S. commercial buildings places a significant burden on the energy supply and is a potential source of economic strain. To address this, the DOE Building Technologies Program has established the goal of developing market-viable zero energy buildings by 2025 . This study focuses on the effects of outside air, and considers various outside air sources, types of building construction, building subsectors, and climates. Based on the information about energy consumption attributed to outside air, it identifies topics for further research that have the greatest potential to achieve energy savings.

15. SUBJECT TERMS

zero energy building; zeb; outside air; ventilation

\begin{tabular}{l}
\hline 16. SECURITY CLASSIFICATION OF: \\
\begin{tabular}{|l|l|l|}
\hline $\begin{array}{l}\text { a. REPORT } \\
\text { Unclassified }\end{array}$ & $\begin{array}{c}\text { b. ABSTRACT } \\
\text { Unclassified }\end{array}$ & $\begin{array}{l}\text { c. THIS PAGE } \\
\text { Unclassified }\end{array}$ \\
\end{tabular} \\
\hline
\end{tabular}

\begin{tabular}{l|l} 
17. LIMITATION & 18. $\begin{array}{l}\text { NUMBER } \\
\text { OF ABSTRACT } \\
\text { OF PAGES }\end{array}$ \\
UL & \\
& \\
\hline
\end{tabular}

19a. NAME OF RESPONSIBLE PERSON

19b. TELEPHONE NUMBER (Include area code) 